\title{
Waste Isolation Pilot Plant Environmental Monitoring Plan
}

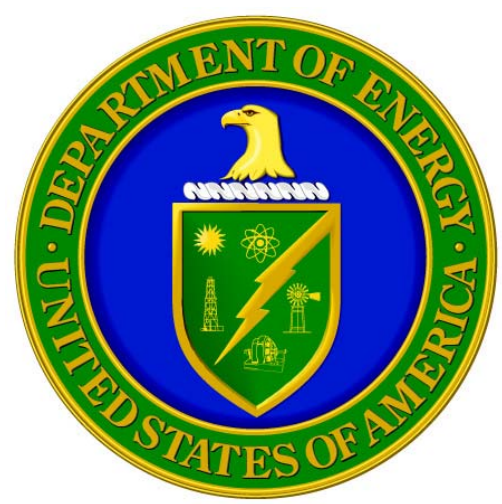

February 2004

Prepared for

U.S. Department of Energy

by

Washington TRU Solutions LLC 
This document has been reproduced directly from the best possible copy. It is available to the DOE and DOE contractors from the following address:

Office of Scientific and Technical Information

P.O. Box 62

Oak Ridge, TN 37831

AVAILABLE TO THE PUBLIC FROM THE NATIONAL TECHNICAL INFORMATION SERVICE

U.S. DEPARTMENT OF COMMERCE

5285 PORT ROYAL ROAD

SPRINGFIELD, VA 22161 


\section{PREFACE}

U.S. Department of Energy (DOE) Order 450.1, Environmental Protection Program, requires each DOE site to conduct environmental monitoring. Environmental monitoring at the Waste Isolation Pilot Plant (WIPP) is conducted in order to:

- Verify and support compliance with applicable federal, state, and local environmental laws, regulations, permits, and orders.

- $\quad$ Establish baselines and characterize trends in the physical, chemical, and biological condition of effluent and environmental media.

- Identify potential environmental problems and evaluate the need for remedial actions or measures to mitigate the problem.

- $\quad$ Detect, characterize, and report unplanned releases.

- Evaluate the effectiveness of effluent treatment and control, and pollution abatement programs.

- $\quad$ Determine compliance with commitments made in environmental impact statements, environmental assessments, safety analysis reports, or other official DOE documents.

This Environmental Monitoring Plan (EMP) has been written to contain the rationale and design criteria for the monitoring program, extent and frequency of monitoring and measurements, procedures for laboratory analyses, quality assurance (QA) requirements, program implementation procedures, and direction for the preparation and disposition of reports. Changes to the environmental monitoring program may be necessary to allow the use of advanced technology and new data collection techniques. This EMP will document any proposed changes in the environmental monitoring program. Guidance for preparation of Environmental Monitoring Plans is contained in DOE/EH-0173T, Environmental Regulatory Guide for Radiological Effluent Monitoring and Environmental Surveillance.

The plan will be effective when it is approved by the appropriate Head of Field Organization or their designee. The plan discusses major environmental monitoring and hydrology activities at the WIPP and describes the programs established to ensure that WIPP operations do not have detrimental effects on the environment. This EMP is to be reviewed annually and updated every three years unless requested by the DOE or contractor. 
THIS PAGE INTENTIONALLY LEFT BLANK 


\section{Waste Isolation Pilot Plant Environmental Monitoring Plan \\ DOE/WIPP 99-2194, Rev. 2}

\section{TABLE OF CONTENTS}

LIST OF TABLES $\ldots \ldots \ldots \ldots \ldots \ldots \ldots \ldots \ldots \ldots \ldots$

LIST OF FIGURES $\ldots \ldots \ldots \ldots \ldots \ldots \ldots \ldots \ldots \ldots \ldots \ldots \ldots \ldots$ vii

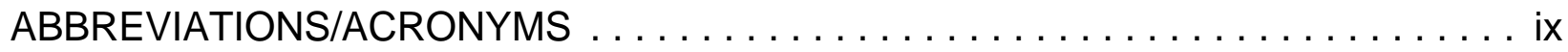

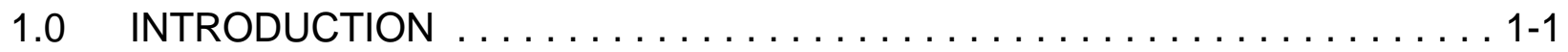

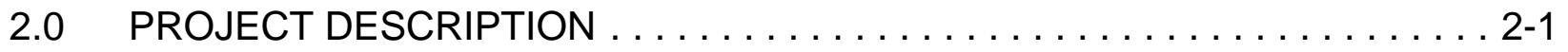

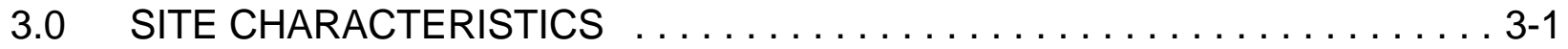

3.1 Geography . . . . . . . . . . . . . . . . . . . . . . . . .

3.2 Geology . . . . . . . . . . . . . . . . . . . . . . . . . . . .

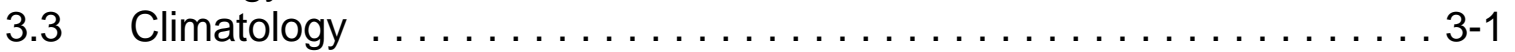

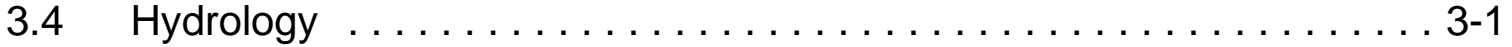

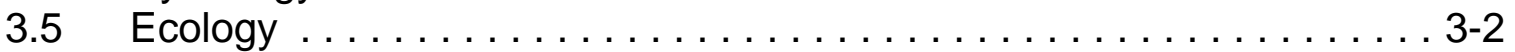

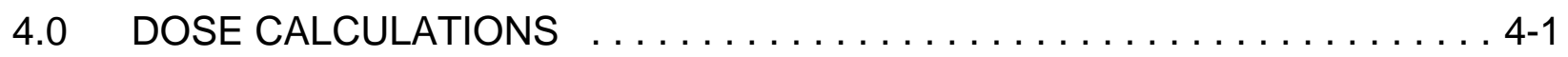

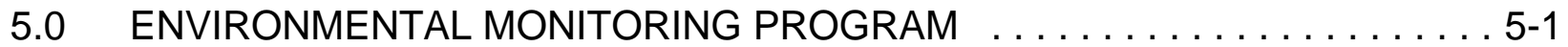

5.1 Guidelines . . . . . . . . . . . . . . . . . . . . . 5-1

5.2 Radiological Environmental Monitoring . . . . . . . . . . . . . 5-3

5.2.1 Effluent Monitoring - Liquid Releases . . . . . . . . . . . . . . 5-3

5.2 .2 Airborne Particulate Sampling . . . . . . . . . . . . . . 5-4

5.2 .3 Biotic Sampling . . . . . . . . . . . . . . . . . . . . . . . 5-5

5.2 .4 Soil Sampling . . . . . . . . . . . . . . . . . . . 5-6

5.2.5 Surface Water/Drinking Water Sampling . . . . . . . . . . 5-7

5.2 .6 Groundwater Sampling . . . . . . . . . . . . . . . . 5-7

5.2 .7 Sediment Sampling ... . . . . . . . . . . . . . . 5-9

$5.3 \quad$ Nonradiological Environmental Monitoring . . . . . . . . . . . . . 5-9

5.3.1 Meteorological Monitoring . . . . . . . . . . . . . . . . . 5-9

5.3.2 Volatile Organic Compound Monitoring Program . . . . . . . . . 5-10

5.3.3 Groundwater Surveillance . . . . . . . . . . . . . . . . . . 5-11

5.3.3.1 Exhaust Shaft Hydraulic Assessment Program . . . 5-11

5.3.3.2 WIPP Shallow Subsurface Water Program . . . . . . 5-11

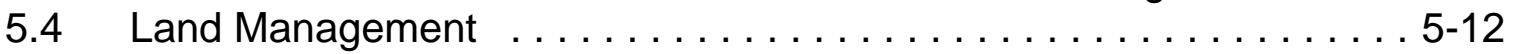

5.4 .1 Oil and Gas Surveillance . . . . . . . . . . . . . . . . . . . 5-12

5.4 .2 Aerial Photography . . . . . . . . . . . . . . . 5-13

6.0 DATA ANALYSES . . . . . . . . . . . . . . . . . . . . 6-1

6.1 Accuracy . . . . . . . . . . . . . . . . . . . . . . . . . . . . . . . . .

6.2 Temporal and Spatial Analysis . . . . . . . . . . . . . . . . 6-3

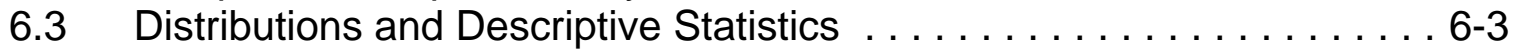

6.4 Data Anomalies . . . . . . . . . . . . . . . . . . . . . 6-3

6.5 Data Comparisons . . . . . . . . . . . . . . . . . . . . . . 6-4

6.6 Laboratory Procedures . . . . . . . . . . . . . . . . . 6-4

6.7 Sample Handling . . . . . . . . . . . . . . . . . 6-4 


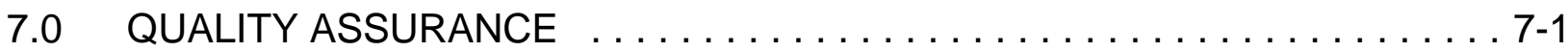

7.1 Goal . . . . . . . . . . . . . . . . . .

7.2 Program Elements/Criteria $\ldots \ldots \ldots \ldots \ldots \ldots \ldots \ldots \ldots \ldots \ldots .3$

7.2 .1 Program . . . . . . . . . .

7.2.2 Personnel Training and Qualification $\ldots \ldots \ldots \ldots \ldots \ldots .4 .4$

7.2 .3 Quality Improvement $\ldots \ldots \ldots \ldots \ldots \ldots \ldots \ldots \ldots \ldots .7 .4$

7.2 .4 Documents and Records $\ldots \ldots \ldots \ldots \ldots \ldots \ldots \ldots \ldots \ldots . .4$

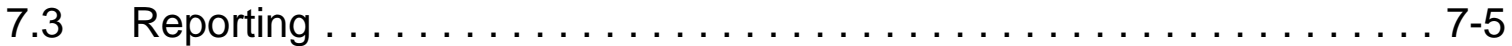

7.3.1 Work Processes $\ldots \ldots \ldots \ldots \ldots \ldots \ldots \ldots \ldots \ldots \ldots$ 7-6

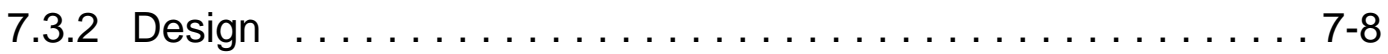

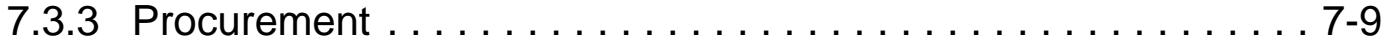

7.3.4 Inspection and Acceptance Testing $\ldots \ldots \ldots \ldots \ldots \ldots \ldots .7-9$

7.3.5 Management Assessment . . . . . . . . . . . . . . . 7-9

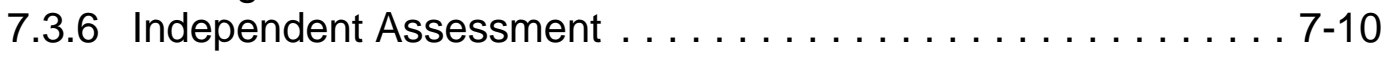

8.0 REFERENCES $\ldots \ldots \ldots \ldots \ldots \ldots \ldots \ldots \ldots \ldots \ldots \ldots \ldots \ldots \ldots$ 8-1 


\section{LIST OF TABLES}

Table 5-1 - Environmental Monitoring Plan Sampling Schedule . . . . . . . . . 5-19

Table 5-2 - EMP Analytical Array . . . . . . . . . . . $\ldots \ldots \ldots \ldots \ldots \ldots$

Table 7-1 - Title 10 CFR 830.120 Cross-Reference to ANSI/ASME NQA-1 and EPA QAMS-005/80 ................... 
THIS PAGE INTENTIONALLY LEFT BLANK 


\section{LIST OF FIGURES}

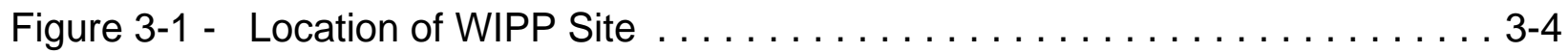

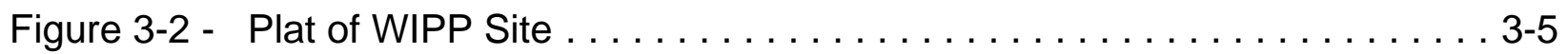

Figure 3-3 - Generalized Stratigraphy of the WIPP Site $\ldots \ldots \ldots \ldots \ldots \ldots \ldots$ 3-6

Figure $5-1$ - Air Sampling Sites . . . . . . . . . . . . . . . . . .

Figure 5-2 - Vegetation/Soil Sampling Sites $\ldots \ldots \ldots \ldots \ldots \ldots \ldots \ldots \ldots$ 5-18

Figure 5-3 - Surface Water Sampling Sites $\ldots \ldots \ldots \ldots \ldots \ldots \ldots \ldots \ldots$ 5-19

Figure 5-4 - Groundwater Level Surveillance Wells . . . . . . . . . . . . . 5-20

Figure 5-5 - Groundwater Sampling Locations . . . . . . . . . . . . . 5-21

Figure 5-6 - Sediment Sampling Sites $\ldots \ldots \ldots \ldots \ldots \ldots \ldots \ldots \ldots \ldots \ldots \ldots \ldots \ldots \ldots \ldots \ldots .22$

Figure 5-7 - Catchment Basins and Meteorological Monitoring Sites . . . . . . 5-23

Figure 5-8 - Locations of SSW Wells (PZ-1 through PZ 12, C-2811, Wells

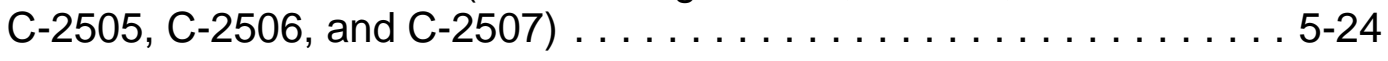


THIS PAGE INTENTIONALLY LEFT BLANK 


\section{ABBREVIATIONSIACRONYMS}

\begin{tabular}{|c|c|}
\hline ANSI & American National Standards Institute \\
\hline ASME & American Society of Mechanical Engineers \\
\hline BLM & Bureau of Land Management \\
\hline CFR & Code of Federal Regulations \\
\hline $\mathrm{CH}$ & contact-handled \\
\hline CMS & central monitoring system \\
\hline DOE & U.S. Department of Energy \\
\hline EDE & effective dose equivalent \\
\hline EDO & environmental data operations \\
\hline EMP & Environmental Monitoring Plan \\
\hline EPA & U.S. Environmental Protection Agency \\
\hline FAS & fixed air sampler \\
\hline FEIS & Final Environmental Impact Statement \\
\hline HEPA & high-efficiency particulate air (filter) \\
\hline Lo-Vol & low-volume \\
\hline LWA & Land Withdrawal Act \\
\hline LUR & land use request \\
\hline MDL & method detection limit \\
\hline MOU & memorandum of understanding \\
\hline MREM & millirem \\
\hline NMAC & New Mexico Administrative Code \\
\hline NMED & New Mexico Environment Department \\
\hline NRC & Nuclear Regulatory Commission \\
\hline NQA & Nuclear Quality Assurance \\
\hline OEMP & Operational Environmental Monitoring Plan \\
\hline OMB & Office of Management and Budget \\
\hline$P Z$ & piezometer \\
\hline QA & quality assurance \\
\hline QAPD & Quality Assurance Program Description \\
\hline $\begin{array}{l}\text { QAPjPs } \\
\text { QC }\end{array}$ & $\begin{array}{l}\text { quality assurance project plans } \\
\text { quality control }\end{array}$ \\
\hline
\end{tabular}


RCRA Resource Conservation and Recovery Act

$\mathrm{RH} \quad$ remote-handled

SAR Safety Analysis Report

SER Site environmental report

SOP standard operating procedure

SSW shallow subsurface water

TDS total dissolved solids

TKN total Kjeldahl nitrogen

TRU transuranic

TRUPACT transuranic package transporter

U.S.C. $\quad$ United States Code

VOC volatile organic compound

WIPP Waste Isolation Pilot Plant

WTS Washington TRU Solutions LLC

WQSP Water Quality Sampling Program 


\section{Waste Isolation Pilot Plant Environmental Monitoring Plan DOE/WIPP 99-2194, Rev. 2}

\section{$1.0 \quad$ INTRODUCTION}

DOE Order 450.1, Environmental Protection Program, requires each DOE site to conduct environmental monitoring. Environmental monitoring at WIPP is conducted to:

- $\quad$ Verify and support compliance with applicable federal, state, and local environmental laws, regulations, permits, and orders.

- $\quad$ Establish baselines and characterize trends in the physical, chemical, and biological condition of effluent and environmental media.

- $\quad$ Identify potential environmental problems and evaluate the need for remedial actions or measures to mitigate the problem.

- $\quad$ Detect, characterize, and report unplanned releases.

- $\quad$ Evaluate the effectiveness of effluent treatment and control and pollution abatement programs.

- $\quad$ Determine compliance with commitments made in environmental impact statements, environmental assessments, safety analysis reports, or other official DOE documents.

This EMP has been written to contain the rationale and design criteria for the monitoring program, extent and frequency of monitoring and measurements, procedures for laboratory analyses, quality assurance (QA) requirements, program implementation procedures, and direction for the preparation and disposition of reports. Changes to the environmental monitoring program may be necessary to allow the use of advanced technology and new data collection techniques.

This EMP will document any proposed changes in the environmental monitoring program. This document is prepared for WIPP in accordance with the guidance contained in applicable sections of Environmental Regulatory Guide for Radiological Effluent Monitoring and Environmental Surveillance (DOE/EH-0173T; DOE, 1991); and the Title 10 Code of Federal Regulations (CFR) Part 834, "Radiation Protection of the Public and Environment" (draft). The WIPP Project is operated by Washington TRU Solutions LLC (WTS) for the DOE.

This plan defines the extent and scope of WIPP's effluent and environmental monitoring and hydrology programs during the facility's operational life and also discusses WIPP's quality assurance/quality control (QA/QC) program as it relates to environmental monitoring. 


\section{Waste Isolation Pilot Plant Environmental Monitoring Plan DOE/WIPP 99-2194, Rev. 2}

In addition, this plan provides a comprehensive description of environmental activities at WIPP including:

- $\quad$ A summary of environmental programs, including the status of environmental monitoring activities.

- $\quad$ A description of the WIPP Project and its mission.

- A description of the local environment.

- $\quad$ An overview of the methodology used to assess radiological consequences to the public.

Environmental activities at the WIPP Project generally fall into four categories:

(1) collect environmental samples in various matrices and analyze them for specific radionuclides; (2) prepare and publish documents showing compliance with federal, state, and local regulations; (3) evaluate whether WIPP activities caused any environmental impacts; and (4) take corrective action when an adverse effect on the environment is identified due to any radiological or nonradiological source.

A number of provisions taken to mitigate potential environmental impacts appear in statements of work issued to all contractors involved in the operation of the WIPP facility. These provisions are listed below:

- $\quad$ Protection of environmental resources, including avoidance of unnecessary damage to vegetation, wildlife, and soil by controlling traffic, minimizing disturbance zones, and cleaning up spills

- $\quad$ Protection of air resources, including the control of hydrocarbon emissions by using proper fuels, the suppression of dust by spraying with water, and the monitoring and control of noise

- $\quad$ Protection of water resources, including the use of retention ponds such as the sewage treatment system for controlling suspended materials, solutes, and other pollutants

- $\quad$ Preservation and recovery of historical, archaeological, and cultural resources, including the interruption of construction activities as necessary to investigate and mitigate impacts to historical or archaeological resources

- $\quad$ Post-construction reclamation, including the removal of temporary construction facilities, access roads, stockpiles, and work areas, as well as the restoration of all damaged landscape features outside the limits of approved work areas.

WIPP must also comply with specified permitting and approval requirements of several federal and state regulating agencies. 


\section{Waste Isolation Pilot Plant Environmental Monitoring Plan DOE/WIPP 99-2194, Rev. 2}

\subsection{PROJECT DESCRIPTION}

The primary purpose of WIPP is to dispose of mixed transuranic (TRU) waste. Mixed wastes are those containing both radioactive and hazardous constituents. The WIPP is allowed to dispose of waste generated by the defense-related activities of the U.S. Government that are specified in the WIPP Hazardous Waste Facility Permit (NMED, 1999).

Contact-handled $(\mathrm{CH})$ waste is being received and disposed of at the WIPP facility. The $\mathrm{CH}$ waste consists of TRU waste that has a surface dose rate of $200 \mathrm{mrem} / \mathrm{hr}$ (millirem per hour) or less and therefore lends itself to direct handling. Remote-handled (RH) waste will be received and disposed of at the WIPP facility in the future when the appropriate permit modification is obtained from the state of New Mexico. The RH waste is TRU waste that, due to higher levels of penetrating radiation, must be shielded and handled remotely. Waste will be classed as $\mathrm{RH}$ when surface dose rate is greater than $200 \mathrm{mrem} / \mathrm{hr}$. TRU waste is radioactive waste that, without regard to source or form, is contaminated with alpha-emitting TRU radionuclides having atomic numbers larger than 92 and half-lives longer than 20 years in concentrations greater than 100 nanocuries per gram of waste.

Waste is delivered to the WIPP Waste Handling Building via semitrailer trucks. $\mathrm{CH}$ TRU waste is shipped in packages known as TRUPACT-Ils (transuranic package transporters). TRUPACT-IIs are durable Type B Nuclear Regulatory Commission (NRC)-certified transport containers designed to accommodate standard waste boxes, ten-drum overpacks, and drums. RH TRU waste will be packaged in waste canisters and shipped to WIPP in NRC-certified, special transportation casks.

The disposal rooms prepared for the waste have been excavated from the Salado Formation, a thick sequence of salt beds deposited 250 million years ago (Permian age). The disposal horizon is located at a depth of 655 meters (2,150 feet).

Within the Waste Handling Building (WHB), waste containers are removed from the TRUPACT-II, secured to a facility pallet for transportation, then placed on the waste-handling hoist and lowered to the disposal horizon. Waste containers are then removed from the hoist and emplaced within the disposal rooms.

When a room is deemed full, ventilation barriers are erected. At that time, waste disposal in the next disposal room commences. When all of the rooms of a panel are full, bulkheads will be installed to seal the panel.

When WIPP is decommissioned, specially designed seals, and closure systems will be placed in the excavated shafts and in the drifts. Geologic pressures and the plasticity of the salt will result in the excavation's gradual closure due to creep. This closure will encapsulate and isolate any waste within the Salado Formation.

The underground area is ventilated by air entering via the salt-handling, air-intake, and waste-handling shafts and exiting through the exhaust shaft. In the event of an accident 
involving waste in the underground, waste-handling activities will cease. Air from the exhaust shaft will be directed, at a reduced flow rate, through the Exhaust Filter Building, which contains banks of high-efficiency particulate air (HEPA) filters in order to remove potentially contaminated particulate. Exhaust ventilation from the WHB is continuously HEPA filtered and is not expected to represent a significant release point. Effluent monitoring is discussed in Section 5.0. 


\subsection{SITE CHARACTERISTICS}

\subsection{Geography}

WIPP is located in Eddy County in southeastern New Mexico (Figure 3-1) within the Pecos Valley section of the southern Great Plains physiographic province (Powers et al., 1978). The site is $42 \mathrm{~km}$ (26 miles) east of Carlsbad in an area known as Los Medaños (the dunes). Los Medaños is a relatively flat, sparsely inhabited plateau with little surface water. The WIPP site (Figure 3-2) consists of 16 sections of federal land in Township 22 South, Range 31 East.

\subsection{Geology}

Los Medaños soils are sandy and well drained, with a well-developed caliche layer occurring below one meter. There are no integrated natural surface drainage features at the site. Scattered throughout the local area are numerous livestock watering ponds (tanks) and shallow playas which retain water sporadically. These playas are located approximately seven miles southwest of the site. Geologically, the site is located in the northern portion of the Delaware Basin, one of the western-most sedimentary basins known collectively as the Permian Basin. Figure 3-3 illustrates the local stratigraphy.

\subsection{Climatology}

Regional climate is semiarid with generally warm temperatures. Average annual precipitation is approximately 31 centimeters (12 inches). About half of the precipitation is received from June through September in the form of high intensity-short duration thunderstorms. Daytime summer temperatures consistently exceed $32^{\circ} \mathrm{C}\left(90^{\circ} \mathrm{F}\right)$ and often rise above $38^{\circ} \mathrm{C}\left(100^{\circ} \mathrm{F}\right)$. Winter temperatures often rise as high as $21^{\circ} \mathrm{C}\left(70^{\circ} \mathrm{F}\right)$ during the afternoon. Nighttime lows during winter average near $-5^{\circ} \mathrm{C}\left(23^{\circ} \mathrm{F}\right)$, occasionally dipping below $-10^{\circ} \mathrm{C}\left(14^{\circ} \mathrm{F}\right)$. Prevailing winds are from the southeast; however, strong winds are common and can blow from any direction, creating potentially violent windstorms which carry large volumes of dust and sand. The wind direction and velocity data have remained essentially the same from year to year. Compilations of climatic data are provided in the annual Site Environmental Report (SER) (DOE, 2003a).

\subsection{Hydrology}

The nearest large surface water body is located approximately 13 kilometers (eight miles) west-southwest of the WIPP site in Nash Draw. The Pecos River is located 22.4 kilometers (14 miles) southwest of the WIPP site.

Several water-bearing zones have been studied near WIPP. The most significant are the Culebra and Magenta members of the Rustler Formation, which consist primarily of fractured dolomite. These dolomite units produce brackish to saline water. Another saline water-bearing zone identified is the Rustler-Salado contact, which contains very little water at the WIPP site. It was exposed during shaft construction and produced 


\section{Waste Isolation Pilot Plant Environmental Monitoring Plan DOE/WIPP 99-2194, Rev. 2}

only a small amount of brine seepage. Other water-bearing zones that have been evaluated as part of site characterization include the Dewey Lake Redbeds and the overlying Triassic Dockum Group and the Bell Canyon and Castile Formations.

The Dewey Lake Formation (Figure 3-3), which contains limited amounts of fresh water, is composed of alternating thin, even beds of siltstone and mudstone with lenticular interbeds of fine-grained sandstone. Exploratory drilling during site hydrogeologic evaluation did not identify a continuous zone of saturation within the Dewey Lake. The few Dewey Lake wells yielding water for domestic and stock purposes are believed to be completed in the thin, discontinuous lenticular sands where favorable groundwater recharge occurs (Mercer, 1983).

Shallow subsurface water (SSW) occurs beneath the WIPP site at a depth of less than 100 feet below ground surface at the contact between the lower Santa Rosa Formation and the upper Dewey Lake Formation. This SSW yields generally less than 1 gallon per minute in monitoring wells and piezometers (PZs) and contains high concentrations of total dissolved solids (TDS) and chlorides. The origin of this water is believed to be primarily from anthropogenic causes, with some contribution from natural sources. The SSW occurs not only under the WIPP site surface facilities but also about a half mile south of the Waste Handling Shaft.

The SSW saturated zone occurs in the uppermost Permo-Triassic Dewey Lake Formation and basal Triassic Santa Rosa Formation. Some wells in the PZ series produced dry cuttings in the uppermost Dewey Lake Formation, indicating that saturation was limited to the Santa Rosa/Dewey Lake formational contact.

\subsection{Ecology}

The biota of Los Medaños represent a transition between the northern Chihuahuan Desert and the southern Great Plains. The soils at the site include sandy surface soils with intermittent deep sand range sites, to include windblown particles, a thin soil crust, and a layer of moist subsoil. These sandy soils form stabilized coppice dunes interspersed with swales.

Shrubs and grasses are the most prominent components of the local flora. The area is composed of combined Havard shin oak (oak shinnery) dune and grassland aspects that include perennial grasses (e.g., gramma, dropseed, 3-awns) and shrubs (e.g., Fourwing saltbush). These are typical grassland and shrub land species that dominate the flora of the area.

The area supports an abundant and diverse population of mammals. Black-tailed jackrabbits and desert cottontails are the most conspicuous. Other primary mammals include desert mule deer, desert dwelling rodents, and carnivores such as the coyote, gray fox, badger, and striped skunk.

A large variety of bird species are also found in the region. Densities vary according to food and habitat availability. Scaled quail, mourning dove, loggerhead shrike, 


\section{Waste Isolation Pilot Plant Environmental Monitoring Plan}

DOE/WIPP 99-2194, Rev. 2

pyrrhuloxia, and black-throated sparrows are but a few examples of the array of bird inhabitants. The Harris hawk, Chihuahuan raven, Swainson's hawk, Northern harrier, and American kestrel are also found at the site.

Numerous varieties of amphibians and reptiles also occupy the vicinity. Characteristic reptiles in the region include the western box turtle, side-blotched lizard, western whiptail, bullsnake, and prairie rattlesnake. Representative amphibians are the tiger salamander, green toad, and plain's spadefoot.

A brief summary of the ecological baseline surveys appears in Appendix $\mathrm{H}$ of the Final Environmental Impact Statement (FEIS; DOE, 1980). Changes observed in the area ecology will be noted in the SER (DOE, 2003a). 

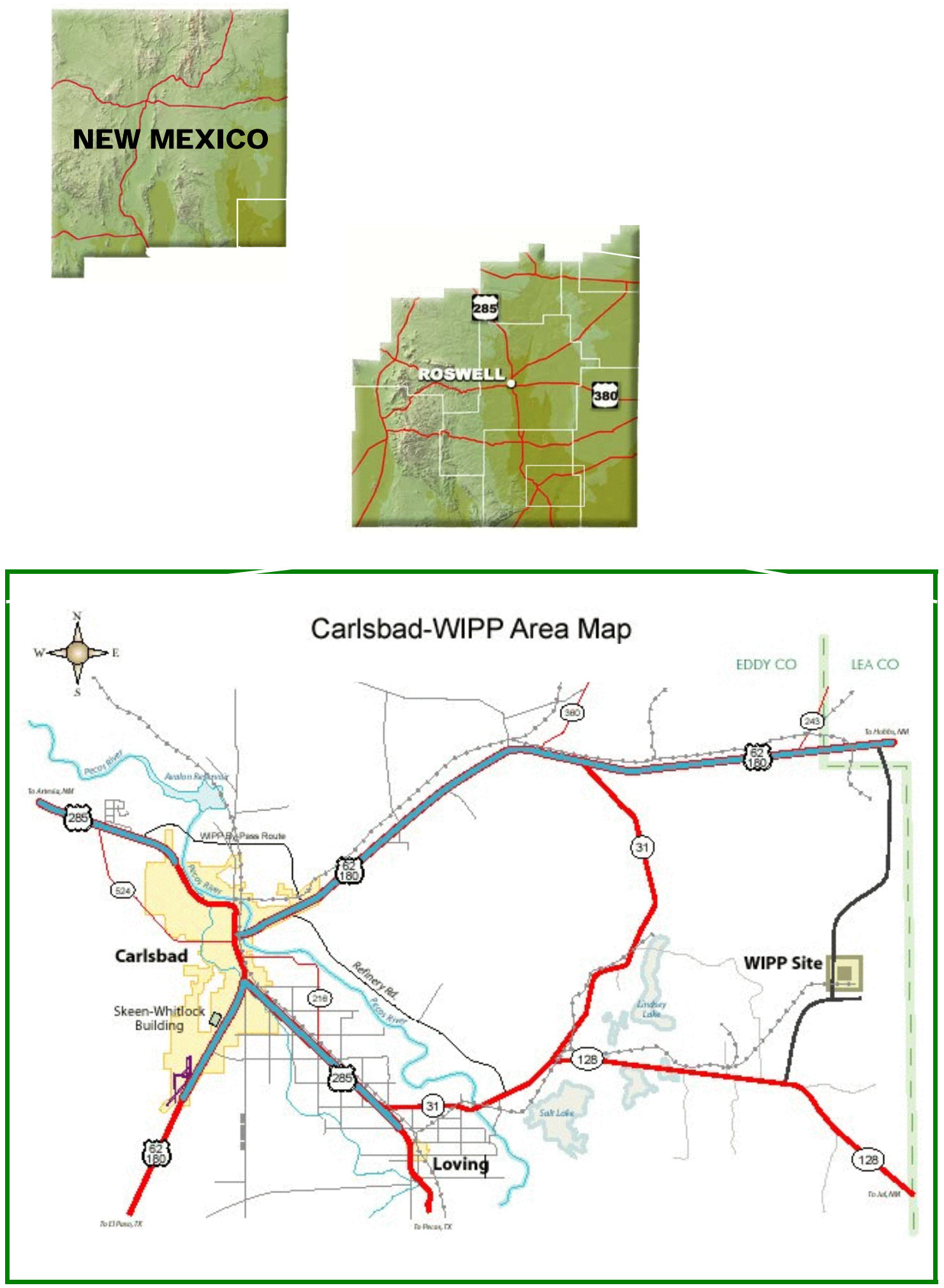

Figure 3-1 - Location of WIPP Site 


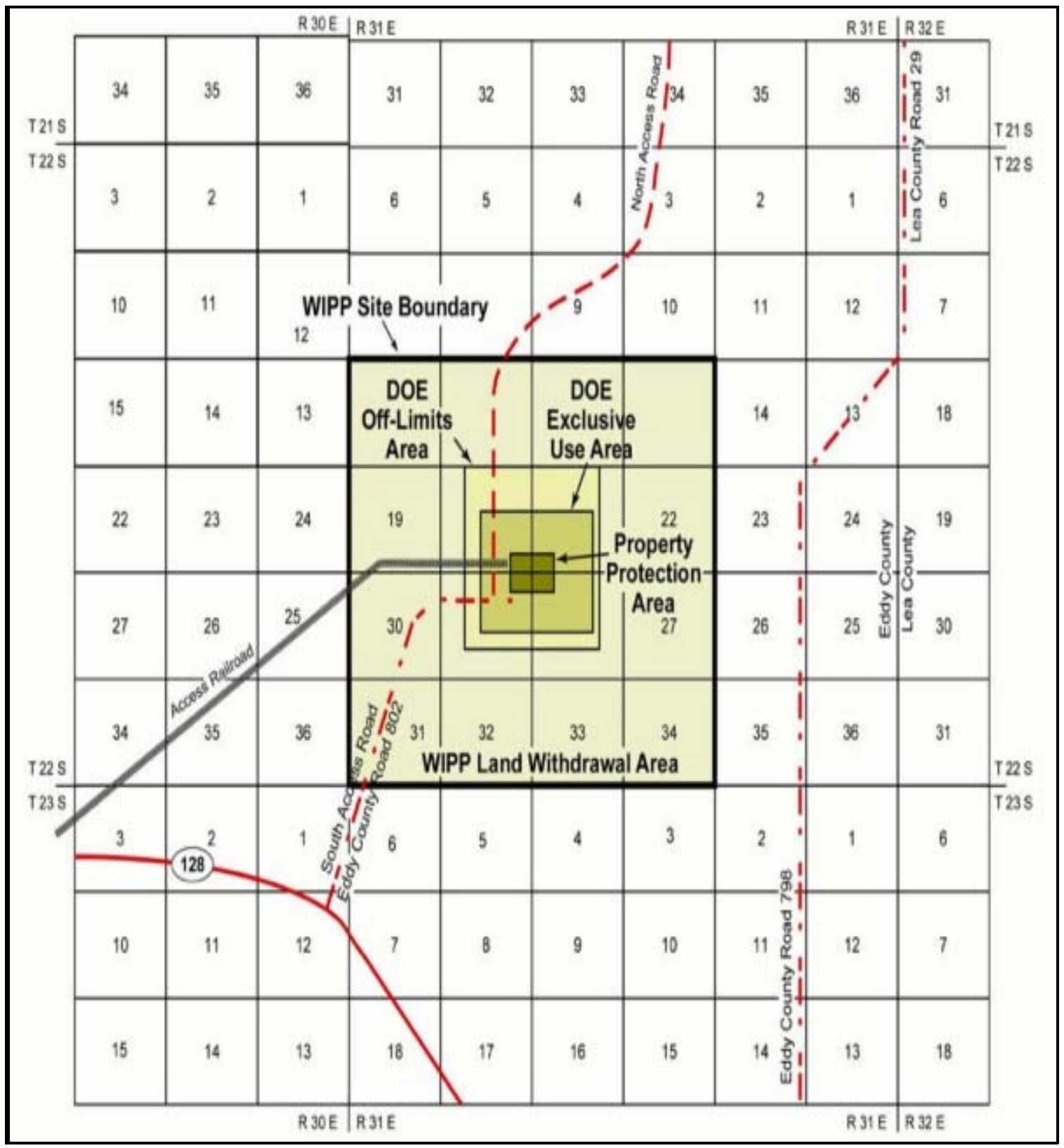

Figure 3-2 - Plat of WIPP Site 


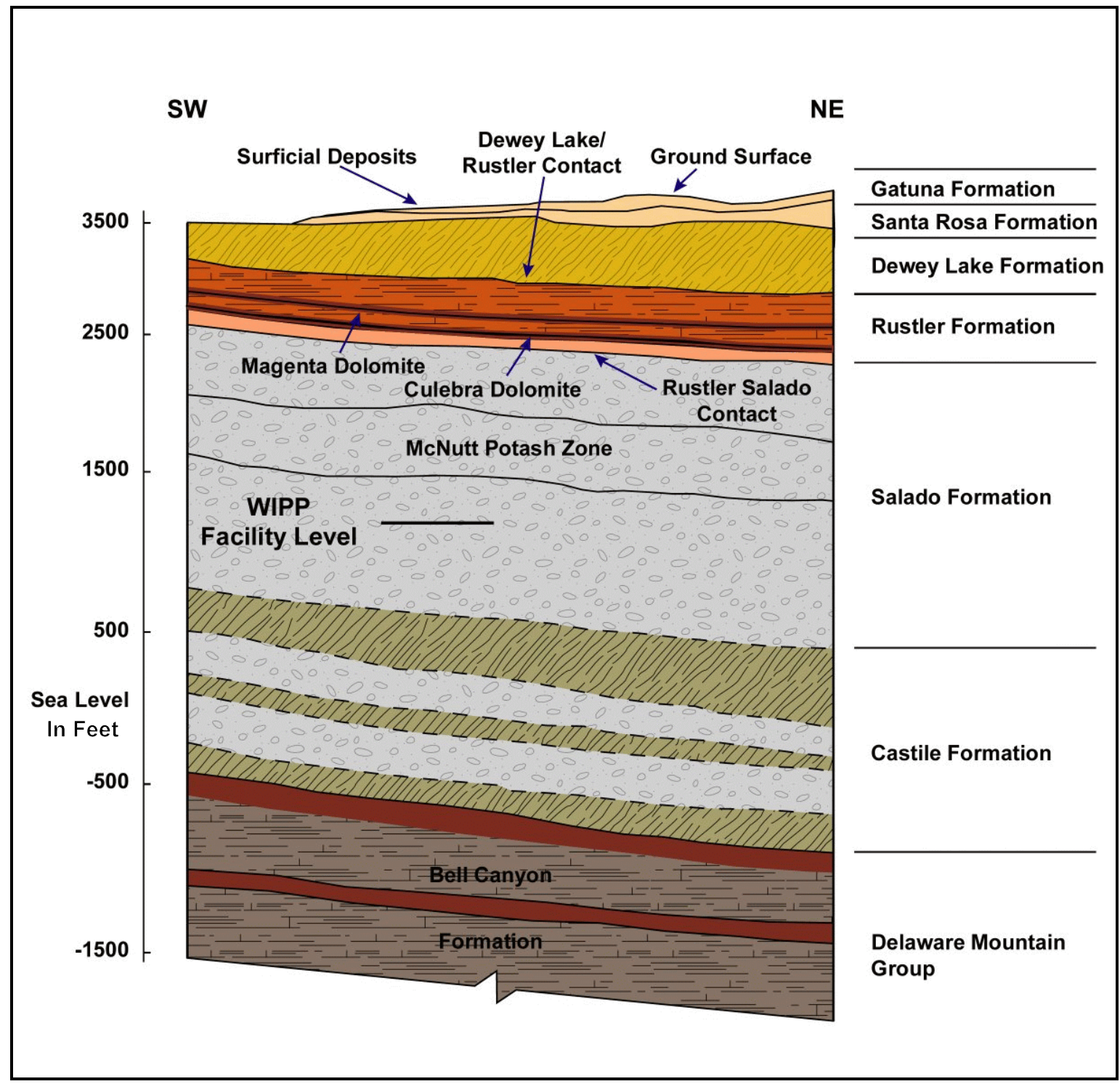

Figure 3-3 - Generalized Stratigraphy of the WIPP Site

(Not to Scale) 


\section{Waste Isolation Pilot Plant Environmental Monitoring Plan DOE/WIPP 99-2194, Rev. 2}

\subsection{DOSE CALCULATIONS}

This section discusses dose calculations involving off-site dose assessment. Sections 7.1.4.1 (On-Site Dose Assessment) and 7.1.4.2 (Off-Site Dose Assessment) of the WIPP Safety Analysis Report (SAR) (DOE, 1997a) state: "Waste containers accepted for disposal at the WIPP are expected to meet the 10 CFR Part 835 external contamination limits." Therefore, WIPP normal operations do not involve or entail any planned or expected releases of airborne radioactive materials.

The WIPP is in compliance with the reporting requirements established by 40 CFR Part 61, Subpart H, "National Emissions Standards for Emissions of Radionuclides Other Than Radon From Department of Energy Facilities," and a Memorandum of Understanding (MOU) dated May 16, 1995, between the U.S. Environmental Protection Agency and the Department of Energy regarding the provisions of the National Emission Standards for Hazardous Air Pollutants for radionuclides.

Emission monitoring and compliance procedures for DOE facilities (40 CFR §61.93[a]) require the use of CAP88-PC (Clean Air Act Assessment Package-1988) or AIRDOS-PC computer models, or other approved procedures, to calculate effective dose equivalents (EDEs) to members of the public. Calculations made utilizing the CAP88-PC indicate that the EDE to the maximally exposed individual resulting from normal operations conducted at the WIPP facility is well below the 10 mrem per year limit. This meets the requirements of 40 CFR Part 61, Subpart H, and 40 CFR Part 191, Subpart A, "Environmental Standards for Management and Storage," for periodic confirmatory sampling.

Nonradiological exposure to members of the public associated with potential airborne chemical releases from the WIPP facility during normal operations is not expected to occur. This expectation is based on the following three factors: (1) extensive site exposure measurements and calculations, which indicate that employee exposures are being maintained well below Occupational Safety and Health Administration permissible exposure limits (as stipulated in 29 CFR §1910.1000); (2) all chemicals used on site must receive approval prior to purchase, with approval based on the minimization of personnel exposure and environmental impact; and (3) nonradiological environmental monitoring activities are being conducted to document any changes in the environment. 
THIS PAGE INTENTIONALLY LEFT BLANK 


\section{Waste Isolation Pilot Plant Environmental Monitoring Plan DOE/WIPP 99-2194, Rev. 2}

\subsection{ENVIRONMENTAL MONITORING PROGRAM}

Each facility is required to ensure the early identification of, and appropriate response to, potential adverse environmental impacts associated with DOE operations. This must include appropriate preoperational characterization and assessment, and effluent and surveillance monitoring. The DOE has complied with this requirement by compiling preoperational radiological and nonradiological data.

An analysis of the historical preoperational data is contained in the following four documents: Statistical Summary of the Radiological Baseline for the WIPP (DOE, 1992a); Summary of the Salt Impact Studies at the WIPP, 1984 to 1990 (DOE, 1992b); A Study of Disturbed Land Reclamation Techniques for the WIPP (DOE, 1992c); and Background Water Quality Characterization Report for the WIPP (DOE, 1992d).

The environmental sampling programs used to establish the preoperational study were originally defined in Chapter 5 of the Operational Environmental Monitoring Plan (OEMP; DOE, 1989). The OEMP evolved into this WIPP EMP. This plan describes the current environmental monitoring efforts at WIPP during the disposal phase. The environmental monitoring data being collected are compiled as a confirmatory tool to quantify unplanned radiological occurrences. The environmental data are published annually in the SER (DOE, 2003a).

The Environmental Monitoring and Hydrology Section at WIPP is administered by the Washington Regulatory and Environmental Services organization of Washington Group International to ensure compliance with pertinent environmental regulations and conduct environmental surveillance to monitor any effects of DOE activities on-site and off-site.

\section{$5.1 \quad$ Guidelines}

Presidential Executive Order 12088, Federal Compliance with Pollution Control Standards, further requires the heads of executive agencies to ensure that all federal facilities and activities comply with applicable pollution control standards and to take all actions necessary for the prevention, control, and abatement of environmental pollution.

It is the policy of the DOE to conduct effluent monitoring and environmental surveillance programs that are appropriate for determining adequate protection of the public and the environment during DOE operations and to ensure that operations comply with DOE and other applicable federal, state, and local radiation standards and requirements. It is the DOE's objective that all DOE operations properly and accurately measure radionuclides in effluent streams and in the ambient environmental media.

A Guide for Environmental Radiological Surveillance at DOE Installations (Corley et al., 1981) states that the factors that should be considered in determining the relative level of environmental surveillance required at a facility include the following:

- $\quad$ Potential hazard of the materials released, considering both expected quantities and relative radiotoxicities 


\section{Waste Isolation Pilot Plant Environmental Monitoring Plan DOE/WIPP 99-2194, Rev. 2}

- $\quad$ Extent to which facility operations are routine and unchanging

- $\quad$ Need for supplementing and complementing effluent monitoring

- Size and distribution of the exposed population

- Cost-effectiveness of increments to the environmental surveillance program

- $\quad$ Availability of measurement techniques that will provide sufficiently sensitive comparisons with applicable standard and background measurements

The above guidance, the risk analysis in the WIPP SAR, and the dose criteria in DOE Order 5400.5, Radiation Protection of the Public and the Environment (DOE, 1990), indicate that operational dose estimates for WIPP are significantly below dose criteria. The WIPP EMP encompasses a comprehensive set of parameters that detect environmental impacts. Also, the EMP scope and intensity are adjusted in response to changing facility processes, environmental parameters, and program results.

Parameters measured include environmental radiation analysis of air, surface water and groundwater; sediments, soils, and biota; the status of the local biological community; and groundwater quality measurements. Nonradiological portions of the program focus on the immediate area surrounding the site, whereas radiological surveillance generally covers a broader geographical area including nearby ranches, villages, and cities. Environmental monitoring will continue at the site during project operations and through decommissioning and beyond.

The goal of the environmental monitoring program is to determine if the local ecosystem has been impacted during the predisposal and disposal phases of WIPP and, if so, to evaluate the severity, geographic extent, and environmental significance. Tables 5-1 and 5-2 summarize the EMP sampling schedule and analytical array. These tables list the sample types, number of sampling stations, approximate sampling schedule, and the environmental/ecological parameters monitored or analyzed. It is important to emphasize the need for flexibility in the design and implementation of the EMP. Additional or different types of samples will be collected and analyzed as necessary to investigate and explain trends or anomalies that may have a bearing on WIPP's environmental impacts. Environmental and ecological sampling during operations will be adjusted to fit the needs of the project.

The geographic scope of radiological sampling is based on projections of potential release pathways for the types of radionuclides in WIPP wastes. Also, the surrounding population centers are monitored, even though release scenarios involving radiation doses to residents of those population centers are improbable.

Sampling and related activities are conducted in accordance with the procedures and instructions described in the WIPP procedures. Standard sampling practices and techniques are used (see Section 6.0, Data Analysis). 


\section{Waste Isolation Pilot Plant Environmental Monitoring Plan DOE/WIPP 99-2194, Rev. 2}

QA/QC has been established within the framework of WP 13-1, Washington TRU Solutions LLC Quality Assurance Program Description (QAPD), and is described in Section 7.0 of this EMP. When the WIPP data are received, they are evaluated and presented in the SER (DOE, 2003a).

\subsection{Radiological Environmental Monitoring}

The operational environmental surveillance program will continue, with some modifications of the preoperational program and parameters monitored during the Radiological Baseline Program and Ecological Monitoring Program, during the disposal phase. Each sampling subprogram of the EMP is described below.

\subsubsection{Effluent Monitoring - Liquid Releases}

DOE Order 5400.5 is the DOE driver that sets dose limits and requires monitoring of liquid effluent streams. The Environmental Regulatory Guide for Radiological Effluent Monitoring and Environmental Surveillance (DOE, 1991) is the guidance document that sets the standard for meeting the requirements of DOE Order 5400.5. Liquid effluent monitoring is necessary to quantify radionuclides released to the environment and to alert operators of process inconsistences and malfunctions of emission controls.

There is no direct connection between the WHB and the sewage treatment system; therefore, there is no direct pathway for radioactive or hazardous contaminants associated with the TRU wastes to enter the WIPP sewage treatment system. There is a sump in the WHB that collects liquids from throughout the WHB. Should there ever be any liquid accumulation in the sump, as a result of a waste package release or subsequent fire-suppression water collection, the water in the sump will be sampled and analyzed for contamination as shown in Table 5-2. The following would then be performed to ensure proper management of the waste:

- $\quad$ If the fire water is radioactive, it will be assumed to be TRU mixed waste and will be managed as derived waste. Solidification will occur as the water is transferred to the derived waste drum. Characterization and disposition will be performed in accordance with pertinent conditions, permits, and authorizations (e.g., Hazardous Waste Facility Permit, New Mexico Environment Department [NMED, 1999]).

- If the fire water is nonradioactive, a determination will be made if the water is hazardous waste. The determination will include sampling and analysis. Any waste determined to be nonradioactive hazardous waste will be managed in accordance with the WIPP facility procedures for such waste.

- $\quad$ If the fire water is nonhazardous, as described in the NMED Discharge Plan for the WIPP (DP-831), it will be discharged to the WIPP facility sewage lagoon.

- $\quad$ If the sump contents are radioactive or hazardous, or both, WIPP will remove and solidify the contents of the sump. 


\section{Waste Isolation Pilot Plant Environmental Monitoring Plan DOE/WIPP 99-2194, Rev. 2}

The WIPP sewage treatment system is a zero discharge facility made up of two parallel synthetically lined primary settling lagoons, two polishing cells and three evaporation lagoons. The berm that surrounds the sewage lagoon is designed to prevent storm water inflows and potential discharges. The facility is designed to contain normal sewage effluent and a 100-year/24-hour storm event.

The sewage treatment facility is operated in accordance with a discharge permit issued by NMED issued in January of 1992 and last renewed on April 29, 2003. The discharge permit approves the discharge plan submitted to NMED which outlines operating, monitoring and closure requirements.

As specified in WP 02-EM1001, Sewage Lagoon Sampling, water samples of the influent and final evaporation ponds are collected semiannually. Samples of the influent are analyzed for nitrate $\left(\mathrm{NO}_{3}\right)$, total Kjeldahl nitrogen (TKN), TDS, and radiochemistry $\left({ }^{238} \mathrm{Pu},{ }^{239 / 240} \mathrm{Pu},{ }^{241} \mathrm{Am},{ }^{234} \mathrm{U},{ }^{235} \mathrm{U},{ }^{238} \mathrm{U}\right.$, and $\left.{ }^{90} \mathrm{Sr}\right)$. The evaporation lagoons are sampled for TDS and radiochemistry $\left({ }^{238} \mathrm{Pu},{ }^{239 / 240} \mathrm{Pu},{ }^{241} \mathrm{Am},{ }^{234} \mathrm{U},{ }^{235} \mathrm{U},{ }^{238} \mathrm{U}\right.$, and $\left.{ }^{90} \mathrm{Sr}\right)$.

\subsubsection{Airborne Particulate Sampling}

The atmospheric pathway has been established as the most credible exposure pathway to the public from WIPP. Therefore, airborne particulate sampling for alpha-emitting radionuclides is emphasized in the EMP. Air sampling results are used to trend environmental radiological levels and determine if there has been a deviation from established background radiological levels.

To determine the number of air sampling stations and their placement, demographic and meteorologic data for the site were examined to determine the distance to local population centers, their population, and the wind frequency distribution and weighing factors, which are scaled to equal the desired number of sampling locations. Locations were selected to avoid areas where large-particle (nonrespirable) fugitive dusts can dominate the sample.

Low-volume fixed air samplers (Lo-Vols) operate at an average of two cubic feet per minute ( 0.056 cubic meters/minute) with a maximum of $+/-0.2$ deviation. The sample inlet probes are positioned in accordance with siting criteria contained in regulations and standards in effect at the time. Also, in sites free from unusual micro meteorological or other conditions (e.g., proximity of large buildings, vehicular traffic) that could result in air concentration measurements that are artificially high or low, the inlets are configured to provide a minimum of 270 degree sample radius.

The current Lo-Vol sampling array (Figure 5-1) consists of seven sampling stations, the locations of which are based primarily on meteorological and demographic considerations and the need to provide as much continuity as possible between baseline and operational data. Lo-Vol samplers are at Carlsbad, Smith Ranch, Mills Ranch, WIPP South, WIPP East, WIPP Far Field, and the Southeast Control sites. The Southeast Control site is located approximately 12 miles southeast of WIPP. This air sampling location is a control site in the predominant upwind direction of WIPP. One 


\section{Waste Isolation Pilot Plant Environmental Monitoring Plan DOE/WIPP 99-2194, Rev. 2}

QC sampler is rotated every calendar quarter to a different sampling location to provide added assurance that the air samplers are operating consistently.

Airborne particulate sampling is performed in accordance with WP 02-EM1012, and includes steps for exchanging Lo-Vol filters weekly, desiccation, weighing and transmittal to a laboratory for counting and determining gross alpha and beta activity on a gas flow proportional counter. Quarterly composites of filters from each location undergo specific radionuclides analysis in accordance with Table 5-2.

The WIPP facility has three emission points,

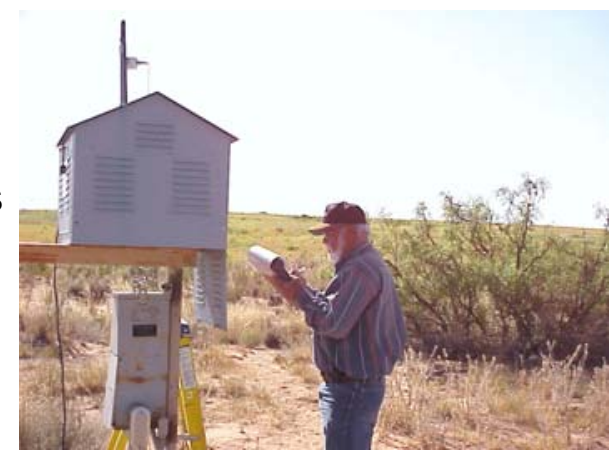
Stations $A, B$, and $C$, that may potentially release airborne radionuclides to the environment. Station A exhausts unfiltered air from the underground repository to the atmosphere. Station B exhausts HEPA filtered air from the underground repository to the atmosphere when in Filtration Mode of operation. Station $\mathrm{C}$ exhausts HEPA filtered air from the Waste Handling Building to the atmosphere. The WIPP facility uses skid-mounted fixed air samplers at each emission point to collect representative samples of airborne particulates. Sample filters are collected at the Station A fixed air sampler (FAS) on a daily basis. Station B filters are collected weekly and at the end of each underground effluent filtration event, and as needed. Station C FAS filters are collected weekly, and as needed. Filters from all three stations are typically analyzed for gross alpha and beta activity. The sample filters are then composited and submitted for isotopic analysis $\left({ }^{238} \mathrm{Pu},{ }^{239 / 240} \mathrm{Pu},{ }^{241} \mathrm{Am}\right.$, and $\left.{ }^{90} \mathrm{Sr}\right)$ either monthly or quarterly depending on the frequency of filter changes from each station. Generally, Station A samples are composited monthly, and Station B and C samples are composited quarterly. The results are reported to the U.S. Environmental Protection Agency (EPA) on an annual basis as described in Section 4.0.

\subsubsection{Biotic Sampling}

In accordance with WP 02-EM1011, Biotic Sampling, collection and analysis of biotic samples accomplishes the following:

- $\quad$ Evaluates the potential radiation doses received by way of human consumption

- $\quad$ Predicts the possible concentrations in available biota

- $\quad$ Monitors trends in environmental contamination and possible long-term accumulation of radionuclides

In accordance with WP 02-EM1019, Vegetation Sampling, vegetation samples are collected from the

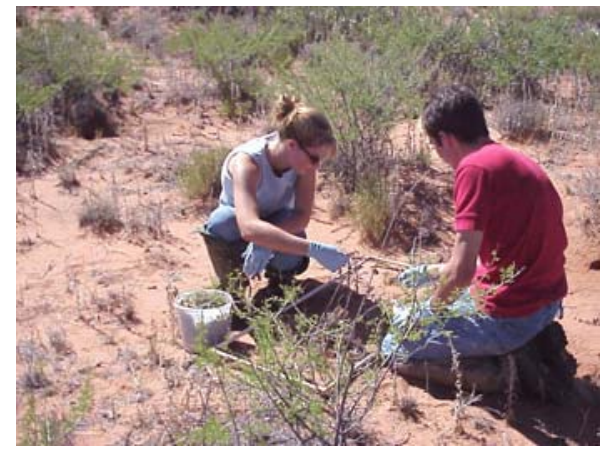
locations where air samples and soil samples are 


\section{Waste Isolation Pilot Plant Environmental Monitoring Plan DOE/WIPP 99-2194, Rev. 2}

collected (Figure 5-2). Collection of multiple media samples at the same location allows for a broad environmental evaluation of a location. In addition, if vegetable gardens are grown at the Smith and/or Mills Ranches, a leafy vegetable sample may be collected annually and analyzed as specified in Table 5-2.

Beef and deer samples are collected on an as-available basis, primarily through livestock and vehicle collisions on the roads in the WIPP vicinity. Tissue and organ samples are collected only if they are easily attainable.

DOE/EH-0173T (DOE, 1991) indicates that game birds and mammals hunted locally should be sampled during the hunting season near (within $25 \mathrm{~km}$ ) the site. Rabbits and quail are collected annually on an as-available basis. Quail are trapped at the facility, while rabbits are collected when found on roads near the WIPP site. A composite sample of muscle tissue from each type of animal is collected. Organ tissue is also collected as available. These samples are analyzed as shown in Table 5-2.

Catfish are collected annually from the Pecos River near Carlsbad; from Brantley Lake, which is located on the Pecos River between Artesia and Carlsbad.

The fish samples are collected and prepared for radiological analysis by removing the head and tail. The samples are composited by location and then analyzed for specific radionuclides activity and the specific radionuclides indicated in Table 5-2. Catfish are appropriate for analysis in this program because

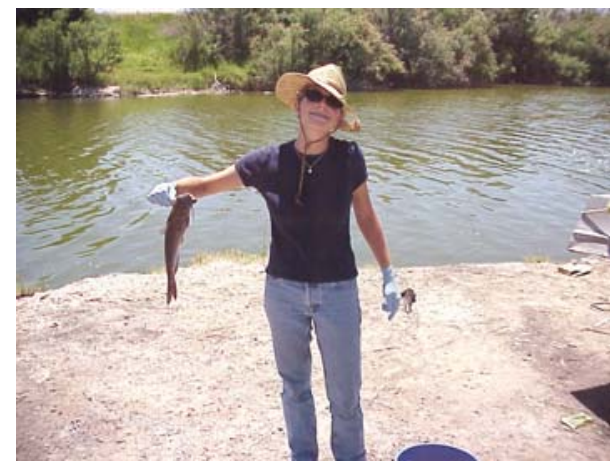
they dwell and feed in bottom sediments where TRU radionuclides may accumulate.

Each sample is collected as specified in WP 02-EM1011. Sufficient material is collected to meet the needs of the analytical laboratory.

\subsubsection{Soil Sampling}

Soil samples are collected annually from the six locations shown in Figure 5-2. Sampling sites are co-located at air particulate sampling locations and the vegetation sampling sites as recommended in HASL-300, Environmental Measurement Laboratory Procedures Manual (DOE, 1997b) and DOE/EH-0173T (DOE, 1991). The frequency of sampling also follows the guidance contained in DOE/EH-0173T for obtaining long-term accumulation trends. Samples are currently being collected at depths of $0-2,2-5$, and $5-10 \mathrm{~cm}$. The soil samples are analyzed as indicated in Table 5-2.

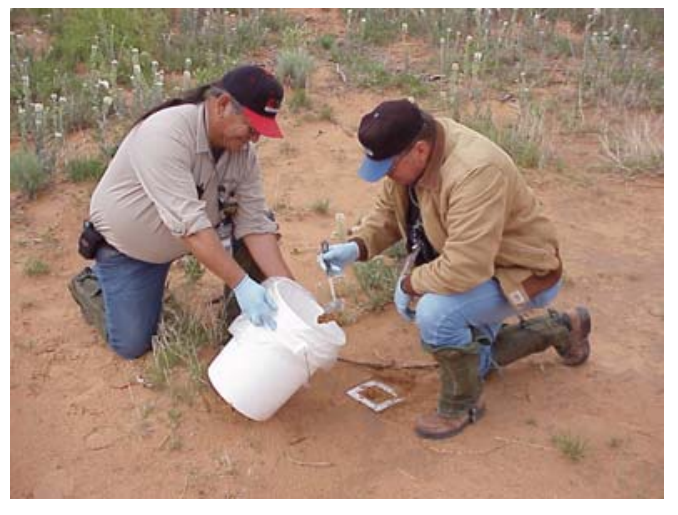




\section{Waste Isolation Pilot Plant Environmental Monitoring Plan DOE/WIPP 99-2194, Rev. 2}

\subsubsection{Surface Water/Drinking Water Sampling}

Surface water is absent within the WIPP Land Withdrawal Area. As specified in WP 02-EM1017, Surface Water and Sediment Sampling for Radiological Analysis, the surface water samples are collected annually from the 14 locations, as available, in the WIPP vicinity specified in Figure 5-3. These locations comprise the major bodies of surface water in the WIPP vicinity and provide adequate data concerning the surface water pathway. Analyses are performed as specified in Table 5-2.

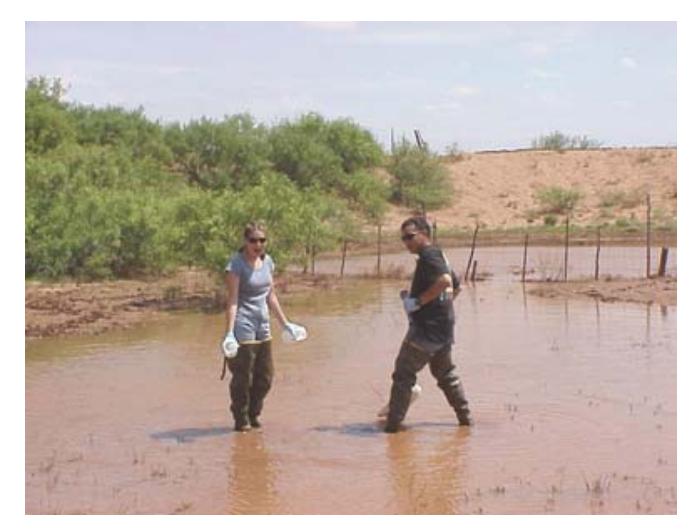

In addition to the regularly sampled surface water locations there are additional "samples of opportunity" collected from the site runoff water catchment basins when there is adequate runoff available to be properly sampled. As standard for most of the surface water sampling sites, a sediment sample is also collected at the same location. Due to the construction of the basins it is not advisable to perforate the clay bottom to collect the sediment samples. Therefore, sediment samples will not be collected from the sites located directly south and west of the WIPP facility.

Drinking water is collected at the pump house from the WIPP water supply system. This is the facility which receives/stores the fresh water that is supplied to the site. This water is sampled annually and analyzed for the constituents listed in Table 5-2.

\subsubsection{Groundwater Sampling}

Groundwater, which may potentially be affected by DOE operations, must be monitored to detect and document the effects of such operations on groundwater quality and quantity, and to show compliance with applicable federal and state laws and regulations. The groundwater monitoring programs should be conducted on-site and near DOE facilities to:

- Obtain data to determine baseline conditions of groundwater quality and quantity.

- Demonstrate compliance with and implementation of all applicable regulations and DOE orders.

- $\quad$ Provide data for the early detection of groundwater pollution or contamination.

- Identify existing and potential groundwater contamination sources and maintain surveillance of these sources.

- $\quad$ Provide data upon which decisions can be made concerning land disposal practices and the management of groundwater resources. 


\section{Waste Isolation Pilot Plant Environmental Monitoring Plan DOE/WIPP 99-2194, Rev. 2}

The WIPP Groundwater Monitoring Program supports the Resource Conservation and Recovery Act (RCRA) Detection Monitoring Program as mandated by 20.4.1 NMAC (New Mexico Administrative Code) and the EPA Compliance Certification Application (DOE, 1996) as mandated by 40 CFR Parts 191 and 194. The Groundwater Monitoring Program consists of two subprograms, the Groundwater Level Monitoring Program and the Water Quality Sampling Program (WQSP).

The Groundwater Level Monitoring Program involves collecting monthly water level measurements from available wells (Figure 5-4) near WIPP. As specified in WP 02-EM1014, Groundwater Level Measurement, the water level monitoring is performed to help characterize the direction and velocity of groundwater flow, to determine the impact of the WIPP site operations on the groundwater-flow system, and to assess the adequacy of point-of-compliance wells to detect groundwater impacts from monitoring facilities. Also, collection of

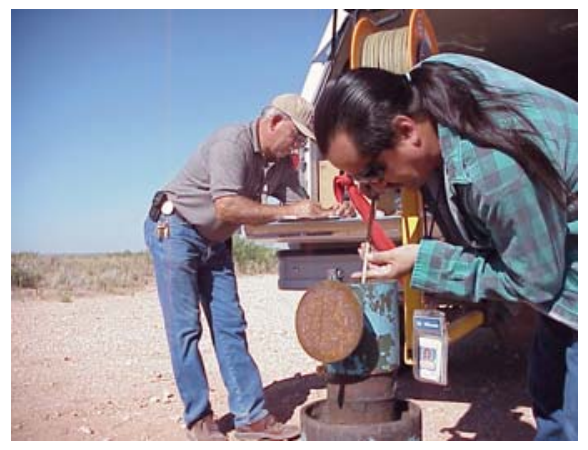
groundwater-level data assists the DOE in meeting performance assessment, regulatory compliance, and permitting requirements.

The WQSP groundwater samples are collected from the wells noted on Figure 5-5. Two types of samples are collected: serial samples and final samples. Serial samples are taken at regular intervals and analyzed in the mobile field laboratory for various physical and chemical parameters, called field indicator parameters. The serial sample data are used to determine whether the sample is representative of undisturbed groundwater as a direct function of the volume of water being purged from the well. Protocols for serial sample analysis are contained in WP 02-EM1005, Groundwater Serial Sample Analysis. Final samples are collected when the groundwater being purged from the well has been determined to have reached a representative state. The final samples are sent to analytical laboratories for analysis of chemical and physical parameters as well as specific radionuclides. The protocols for the collection of final and serial samples are contained in WP 02-EM1006, Final Sample and Serial Sample Collection.

Water quality sampling is performed in seven wells at WIPP. WQSP wells 1-6 are completed in the Culebra member of the Rustler Formation, and WQSP-6a is completed in the Dewey Lake Formation. The wells are constructed to EPA standards and meet the detection monitoring standards under the WIPP Hazardous Waste Facility Permit (NMED, 1999). The analytical results for samples collected from the WQSP wells are reported in the SER (DOE, 2003a). 


\section{Waste Isolation Pilot Plant Environmental Monitoring Plan DOE/WIPP 99-2194, Rev. 2}

\subsubsection{Sediment Sampling}

In accordance with WP 02-EM1017, Surface Water and Sediment Sampling for Radiological Analysis, sediment samples are collected from near the WIPP site annually (Figure 5-6) and analyzed for specific radionuclides noted in Table 5-2. On the Pecos River there are four locations: the upper Pecos near Artesia, New Mexico, Brantley Lake State Park, Lake Carlsbad recreational park, and Pierce Canyon. Eight dirt tanks (earthen catchment basins) are used by area ranchers to collect runoff water for livestock. These tanks are Tut, Noya, Red, Indian, Lost, Bottom-of-the-Hill, Poker Trap, and Hill. Samples are

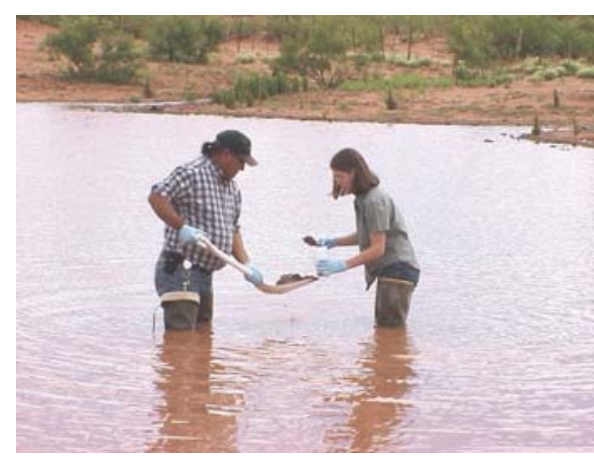
taken from the sewage lagoon outflow when sediment buildup is adequate for sampling purposes. The analytical results for the sediment sample analysis are reported annually in the SER (DOE, 2003a).

\subsection{Nonradiological Environmental Monitoring}

Nonradiological environmental monitoring activities at WIPP consist of a comprehensive set of sampling programs designed to detect and quantify impacts of construction and operational activities. The requirements and objectives of both preoperational and operational nonradiological environmental monitoring are described in the WIPP FEIS (DOE, 1980). The ecological monitoring program functions as an "operational program" both before and after commencement of waste emplacement because it focuses on nonradiological effects, which are ongoing.

Section 2.5 of Appendix J of the FEIS (DOE, 1980) states:

The operational ecological monitoring program, building on the foundation established through preoperational ecological monitoring, will document the ecological effects of construction and operation ... . and will focus primarily on indicator organisms and selected abiotic parameters.

Primary guidance for ecological monitoring was derived from the WIPP FEIS and the American Institute of Biological Scientists evaluation of the WIPP Biology Program. Table 5-2 lists parameters that will be monitored for evidence of possible site impacts. Results of these studies are published in the SER (DOE, 2003a).

\subsubsection{Meteorological Monitoring}

The DOE/EH-0173T manual (DOE, 1991) provides guidance on how each DOE site is to establish a meteorological monitoring program appropriate for the activities at the site and for the local topography and demography. Meteorological data must be monitored and recorded to supplement characterization of the local environment and facilitate the interpretation of data from other environmental monitoring activities at WIPP. WIPP's 


\section{Waste Isolation Pilot Plant Environmental Monitoring Plan \\ DOE/WIPP 99-2194, Rev. 2}

Meteorological program is performed in accordance with the WIPP Meteorological Quality Assurance Plan, WP 02-EM.01, which was written against the guidance contained in Meteorological Monitoring Guidance for Regulatory Modeling Applications (EPA, 2000)

The meteorological monitoring station is a 50-meter tower located northeast of WIPP, as shown in Figure 5-7. Temperature, wind speed, and wind direction are monitored at two, ten, and 50 meters (16, 33, and 165 feet, respectively); barometric pressure, humidity, solar radiation, and precipitation are also monitored at this location. Dew point values are also calculated by the central monitoring system (CMS) from the temperature and humidity values and recorded for future reference. Measurements are

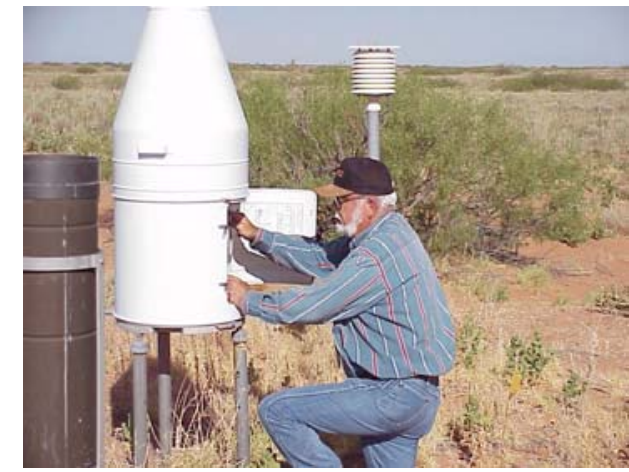
recorded at the CMS, which tracks numerous real-time parameters on a centralized computer system.

\subsubsection{Volatile Organic Compound Monitoring Program}

The Confirmatory Volatile Organic Compound (VOC) Monitoring Program was implemented in accordance with Attachment $\mathrm{N}$ of the Waste Isolation Pilot Plant Hazardous Waste Facility Permit, \#NM4890139088-TSDF, October 27,1999. The monitoring program is designed to determine VOC concentrations attributed to open and closed panels. Nine compounds were chosen to represent the VOCs responsible for approximately 99 percent of the calculated RCRA constituents that posed human health risks.

The VOC Monitoring Program measures VOC concentrations in the ambient air to determine any possible releases from open and closed panels located at WIPP. Air samples are collected at two locations in the underground. One location is upstream from Panel 2 at VOC B. The upstream location (VOC B) measures VOC concentrations attributable to releases from upstream sources and other background sources of VOCs. The downstream location (VOC A) measures upstream sources of VOCs and any additional

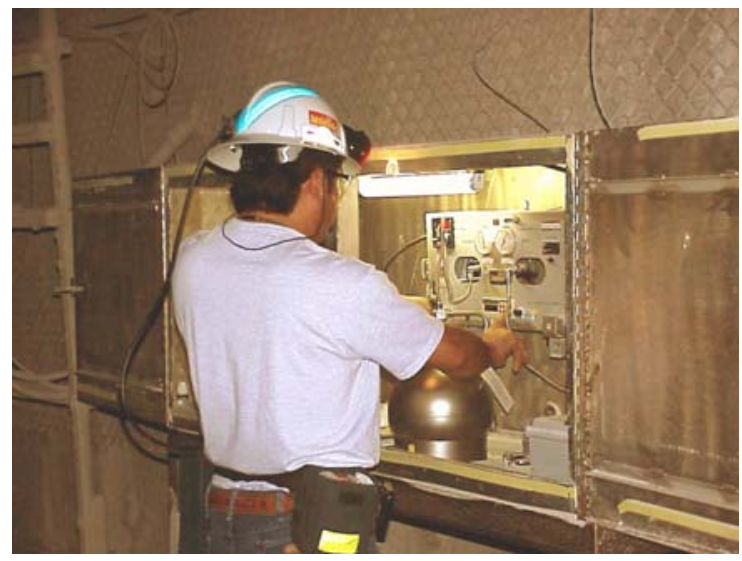
VOCs resulting from releases from the panels. The differences between the two locations should represent the measure of VOCs released from Panels 1 and 2.

VOC sampling is performed using guidance included in Compendium Method TO-14A, Determination of Volatile Organic Compounds (VOCs) in Ambient Air Using Specially Prepared Canisters with Subsequent Analysis By Gas Chromatography (EPA, 1999) as a basis. Analysis of the twice weekly samples is performed by an outside laboratory 


\section{Waste Isolation Pilot Plant Environmental Monitoring Plan DOE/WIPP 99-2194, Rev. 2}

using concepts found in both TO-14A and the draft EPA Contract Laboratory Program Volatile Organics Analysis of Ambient Air in Canisters (EPA, 1994).

\subsubsection{Groundwater Surveillance}

The objective of the WIPP Groundwater Monitoring Program is to establish, by means of groundwater sampling and analysis, an accurate and representative groundwater database that is scientifically defensible and supports regulatory compliance. This surveillance program will document the groundwater quality through time to determine if the water quality is changing. Samples will be collected from the wells noted (Figure 5-3).

General chemistry of the water is monitored using standard wet chemistry analytical methods. These methods will analyze for standard primary constituents such as chlorides, magnesium, calcium, and sulfates. In addition to the general chemistry analysis, data are also gathered for 54 constituents listed in Module $V$ of the Hazardous Waste Facility Permit. Constituents listed in Module $\mathrm{V}$ include metals, purgable volatile compounds,

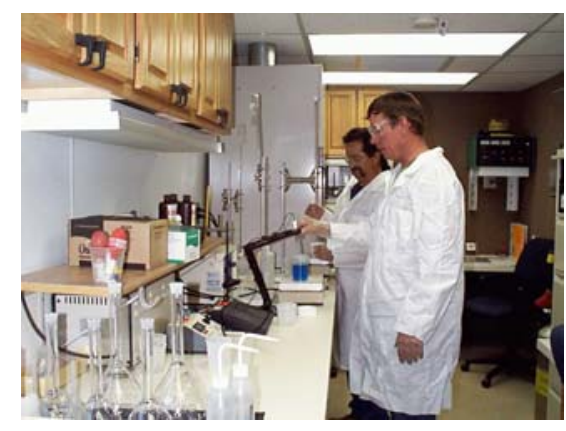
non-purgable volatile compounds, and semivolatile compounds.

\subsubsection{Exhaust Shaft Hydraulic Assessment Program}

The objective of the Exhaust Shaft Hydraulic Assessment Program is to evaluate and monitor the source of water infiltrating through the exhaust shaft liner. Investigations showed a shallow perched water-bearing horizon present at the contact of the Santa Rosa and Dewey Lake Formations. Three wells and twelve PZs were installed over an 80-acre area between September 1996 and July 1997. In March 2001 an additional PZ, $\mathrm{C}-2811$, was installed south of the site (Figure 5-8). A description of the program is provided in DOE/WIPP 03-3177, Geotechnical Analysis Report for July 2001 - June 2002, Volume 1. Water-level measurements are collected quarterly to define the waterlevel surface, while water-quality sampling and analyses are conducted annually to monitor changes in the water chemistry of the shallow water-bearing zone. Water level monitoring and sampling are performed in support of DP-831 (see Section 11).

\subsubsection{WIPP Shallow Subsurface Water Program}

The objective of the WIPP Shallow Subsurface Water (SSW) program is to establish, by means of water level monitoring and water sampling and analysis, an accurate and representative database in support of DP-831. This program will document the SSW quality through time to determine the effectiveness of source control measures noted in the 2003 DP-831 modification. Water levels are taken from all wells noted in Figure 5-8, and samples are taken from a select subset of these wells. Water levels from the SSW program wells will be taken quarterly and water samples will be obtained semiannually. 


\section{Waste Isolation Pilot Plant Environmental Monitoring Plan DOE/WIPP 99-2194, Rev. 2}

General chemistry of the SSW is monitored for parameters expressed in the DP-831 permit, utilizing standard wet chemistry analytical methods. Analysis is performed for selenium, chromium, chloride, sulfate, nitrate, and TDS. Additionally, field indicator parameters are temperature, conductivity, and $\mathrm{pH}$.

In addition to analysis of SSW samples, the four storm water evaporation basins (Figure 5-8) at WIPP are sampled and analyzed for the parameters listed above in support of DP-831. These analyses are used to establish a database of the storm water from the salt storage area and the WIPP facility. Samples of opportunity are collected once per year following a significant storm event.

\section{$5.4 \quad$ Land Management}

Parties who desire to conduct activities that affect lands under the jurisdiction of WIPP, outside the inner core of the facility designated as the Property Protection Area, are required to prepare a land use request (LUR). An LUR consists of a narrative description of the project, a completed environmental review, and a map depicting the location of the proposed activity. The LUR is used to determine if applicable regulatory requirements have been met before the approval of a proposed project. An LUR is submitted to the land use coordinator by any WIPP organization or outside entity wishing to complete any construction, rights-of-way, pipeline easements, or similar actions within the WIPP site boundary and on lands used in the operation of WIPP, under the jurisdiction of the DOE.

\section{Biological and Wildlife Environment}

The wildlife habitat around WIPP is categorized in accordance with the Bureau of Land Management's (BLM) standardized habitat sites subsequent to a detailed integrated habitat inventory classification system. WIPP lands compose a small part of those lands grouped into major habitat types as described in Appendix L-2 of the East Roswell Grazing Environmental Impact Statement. Moreover, habitat types and species inventories were conducted for the DOE during initial site characterization studies as described in the WIPP Biology Program, the FEIS, the Site Preliminary Design and Validation studies, and the EMP. Wildlife near WIPP includes a wide variety of insects, amphibians, reptiles, birds, and mammals.

Results indicated that activities associated with the operation of WIPP have no impact on any threatened or endangered species. Considerations pertaining to protected species are implemented in accordance with pertinent management plan(s) during the deliberation and administration of projects conducted on WIPP lands.

\subsubsection{Oil and Gas Surveillance}

Surveillance of oil and gas activities within one mile of the WIPP boundary is conducted in accordance with

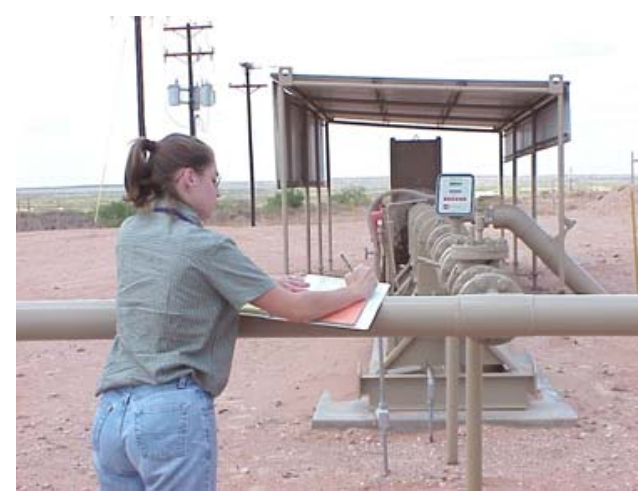




\section{Waste Isolation Pilot Plant Environmental Monitoring Plan \\ DOE/WIPP 99-2194, Rev. 2}

the BLM/DOE MOU. Oil and gas activities within the defined land sectors are monitored twice monthly to identify new activities associated with oil and gas exploration/ production, including:

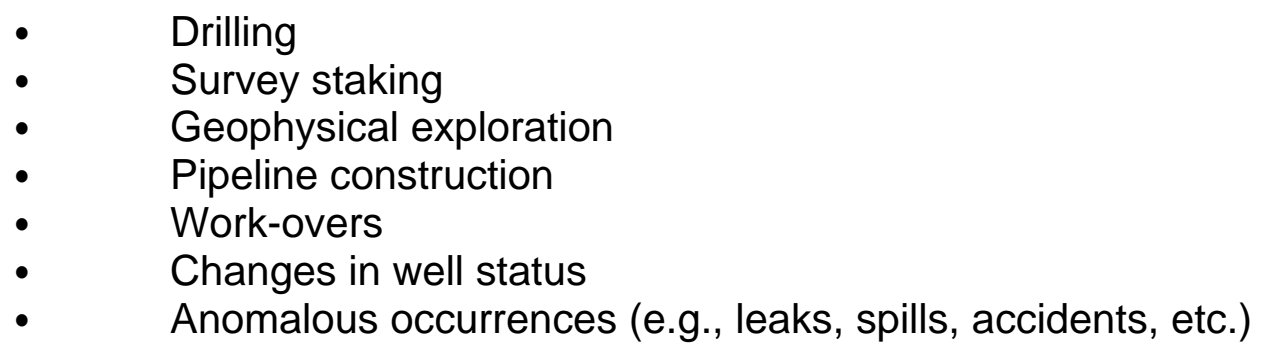

The oil and gas industry is well established in the vicinity of WIPP, with producing oil and gas fields, support services, and compressor stations. Nearly all phases of oil and gas activities have occurred in the locality. These phases include seismic exploration, exploratory drilling, field development (comprised of production and injection wells), and other activities associated with hydrocarbon extraction.

As identified in the BLM's Oil and Gas Potential Occurrence Zones, the Los Medaños region is located in a region designated as having a "high potential for oil and gas occurrence." This region, part of the Delaware Basin, is bordered by the Capitan Reef. Most hydrocarbon extraction has occurred outside the basin, within the reef. Although the Delaware Basin accounts for approximately 32 percent of lands in Eddy County, only 17 percent of the oil and gas wells are located within its boundaries.

WIPP surveillance teams conduct routine surveillances, as well as cursory inspections and additional surveillances as required.

\subsubsection{Aerial Photography}

Aerial photographs are used to document impacts of WIPP activities on the local ecology. Removal of native habitat is due to construction of roads, parking lots, buildings, and salt storage piles. The extent of this habitat displacement is documented in aerial photographs. Photographs may be taken every two to three years.

Aerial photography produces enlarged "spot photos" of the WIPP installation. Project personnel and local emergency response agencies are provided with spot photos for their own use. Selected key locations may be temporarily flagged with conspicuous aerial markers to facilitate their recognition on the aerial photographs. Aerial photographic mission parameters may be altered as necessary to investigate areas of special interest. 
Table 5-1 - Environmental Monitoring Plan Sampling Schedule

Type of Sample

Sampling Locations

Sampling Frequency

Liquid influent

1

Annual

Liquid effluent

DP-831

1

Semiannual

Airborne effluent

3

Continuous

Meteorology

1

Continuous

Air particulate

7

Weekly

Game birds

WIPP vicinity

As available

Rabbits

WIPP vicinity

As available

Beef/deer

WIPP vicinity

As available

Fish

3

Annual

Vegetation

6

Annual

Soil

6

Annual

Surface water*

15

Annual

Sediment

12

Annual

Groundwater

7

Semiannual

Shallow Subsurface Water

Subset of 16

Semiannual

VOCs

2

Semiweekly

Pressure-Density Surveys

Annual

* Site runoff catchment basins 
Table 5-2 - EMP Analytical Array

Type of Sample

Drinking water

Liquid influent/effluent

DP-831

Meteorology

Atmospheric particulate

Biotic (vegetation, rabbits, fish, beef, deer, and quail)

Soil

Surface water

Sediment

Groundwater

Underground VOC Monitoring Program

Aerial photography

Shallow Subsurface Water
Analysis

(1) Specific radionuclides, residual chlorine, coliform, nitrates, elemental lead

(1) Specific radionuclides

$\mathrm{NO}_{3}$, TKN, TDS, ${ }^{238} \mathrm{Pu},{ }^{239 / 240} \mathrm{Pu},{ }^{241} \mathrm{Am},{ }^{234} \mathrm{U}$, ${ }^{235} \mathrm{U},{ }^{238} \mathrm{U}$, and ${ }^{90} \mathrm{Sr}$

Temperature, wind speed, wind direction, precipitation, relative humidity, barometric pressure, and solar radiation

(1) Specific radionuclides, gross alpha, gross beta, and total suspended particulate

(1) Specific radionuclides

(1) Specific radionuclides

(1) Specific radionuclides

(1) Specific radionuclides

(1) Specific radionuclides,

(2) Chemical analysis (field analysis)

(3) Physical properties,

(4) 40 CFR Part 264, specific target compounds of Appendix IX for analysis in groundwater samples

Carbon tetrachloride, chlorobenzene, chloroform, 1,1-dichloroethylene, 1,2-dichloroethane, methylene chloride, 1,1,2,2-tetrachloroethane, toluene, 1,1,1-trichloroethane

Changes occurring to land surface

(1) Selenium, chromium, chloride, sulfate, nitrate, TDS 


\section{Table 5-2 - EMP Analytical Array - Continued}

(1) Specific radionuclides: ${ }^{241} \mathrm{Am},{ }^{60} \mathrm{Co},{ }^{137} \mathrm{Cs},{ }^{40} \mathrm{~K},{ }^{238} \mathrm{Pu},{ }^{239 / 240} \mathrm{Pu},{ }^{90} \mathrm{Sr},{ }^{234} \mathrm{U},{ }^{235} \mathrm{U}$, ${ }^{238} \mathrm{U}$, gross alpha, and gross beta.

(NOTE: Gross alpha and gross beta are only analyzed in the air samples.)

(2) Chemical analysis: antimony, arsenic, barium, beryllium, cadmium, calcium, chloride, chromium, chloroform, cresols, nickel, thallium, vinyl chloride, total organic halogen, total organic carbon, 1,1-dichloroethylene, 1,1-dichloroethane, 1,2-dichloroethane, chlorobenzene, 1,2-dichlorobenzene, 1,4-dichlorobenzene, hexachloroethane, hexachlorobenzene, isobutanol, iron, lead, magnesium, mercury, nitrobenzene, potassium, selenium, silver, carbon tetrachloride, toluene, methylene chloride, pyridine, pentachlorophenol, 2,4-dinitrophenol, 2,4-dinitrotoluene, tetrachloroethylene, 1,1,2,2-tetrachloroethane, methyl ethyl ketone, trichlorofluoromethane, trichloroethylene, 1,1,1-trichloroethane and 1,1,2-trichloroethane, xylenes, cis-1, 2-dichloroethylene, (trans) -1, 2-dichloroethylene, vanadium, sulfate, sodium, and alkalinity.

(3) Physical properties: $\mathrm{pH}$, specific conductance, TDS, density, and total suspended solids.

(4) Title 40 CFR Part 264, specific target compounds of Appendix IX for analysis in groundwater samples 


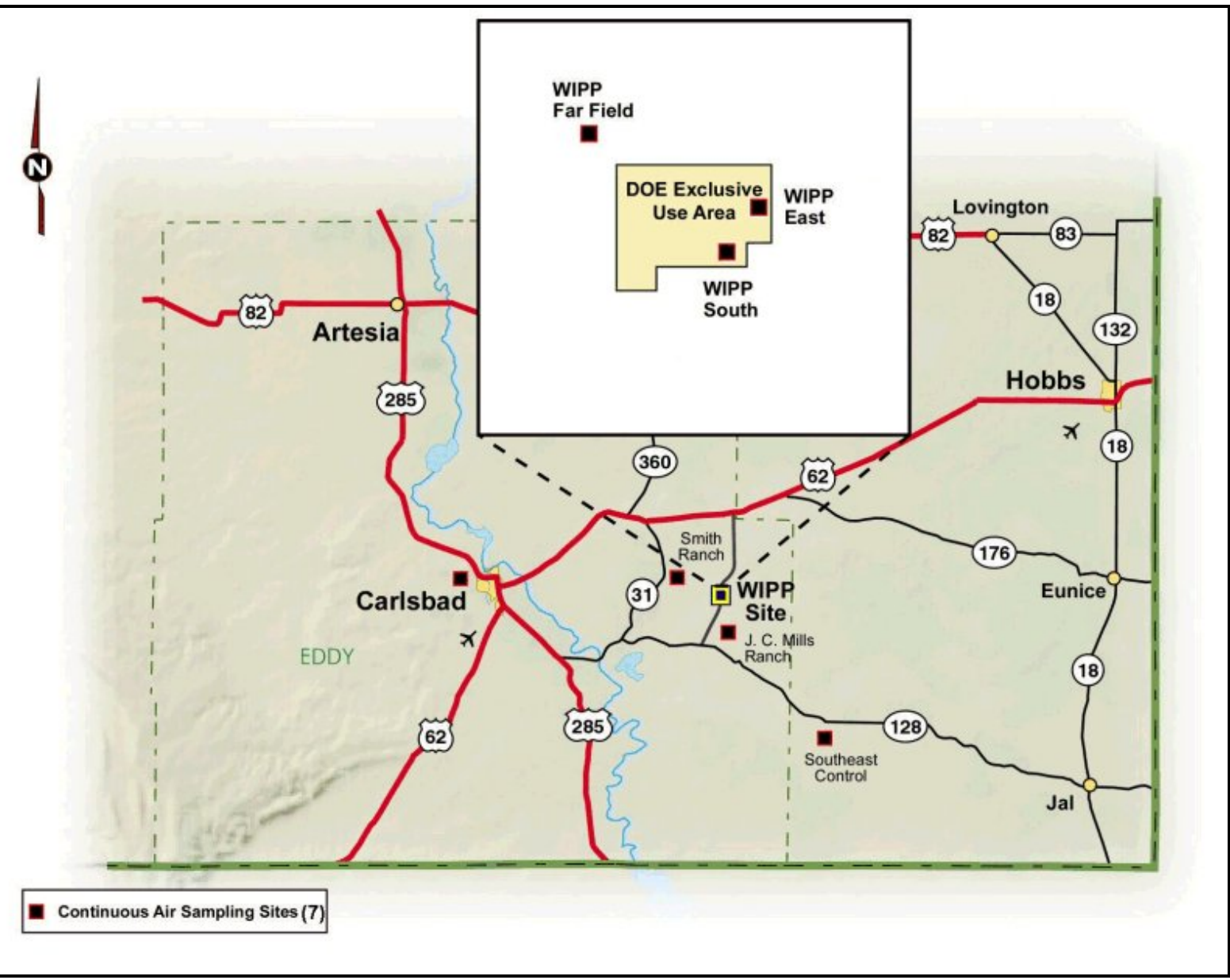

Figure 5-1 - Air Sampling Sites 


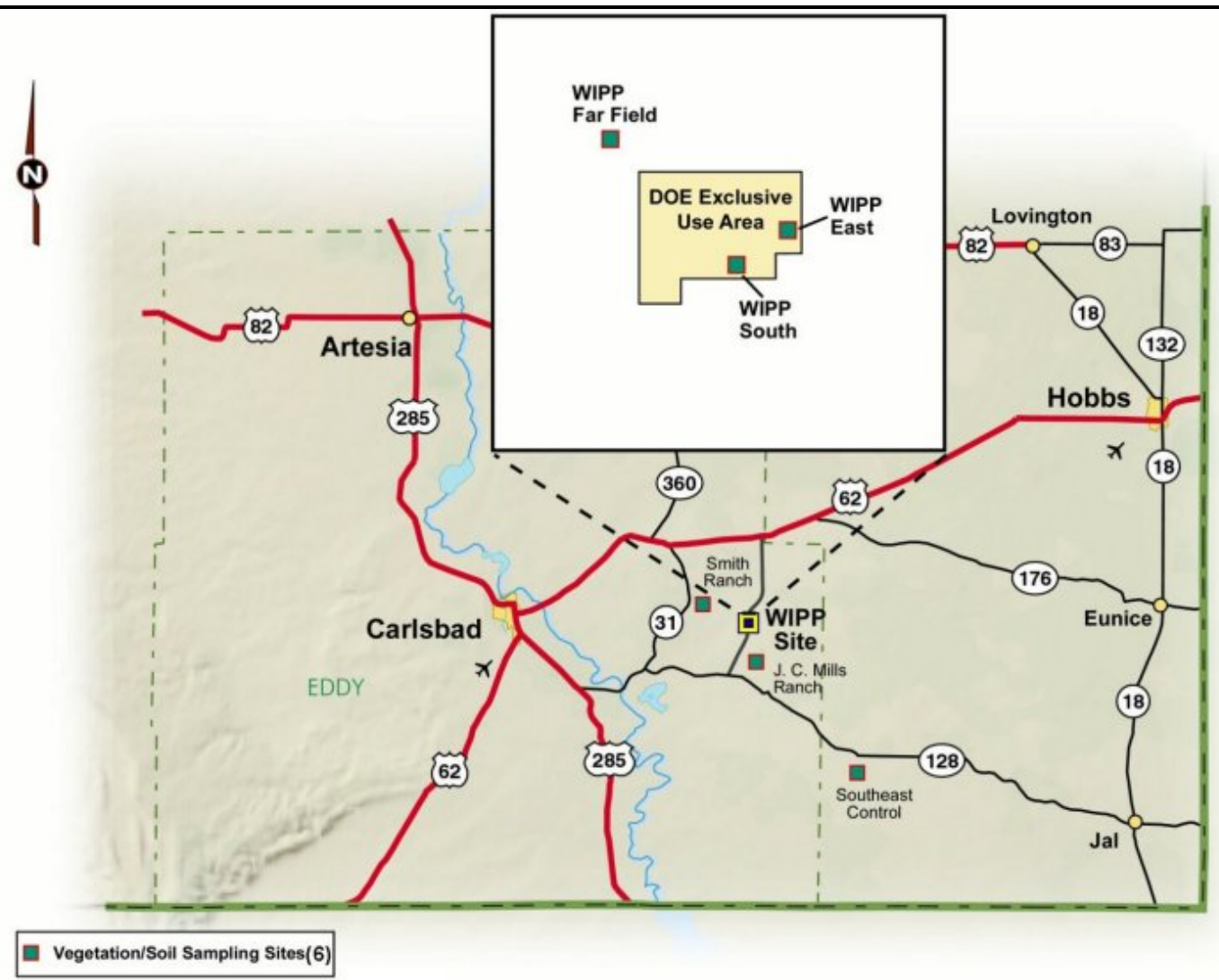

Figure 5-2 - Vegetation/Soil Sampling Sites 


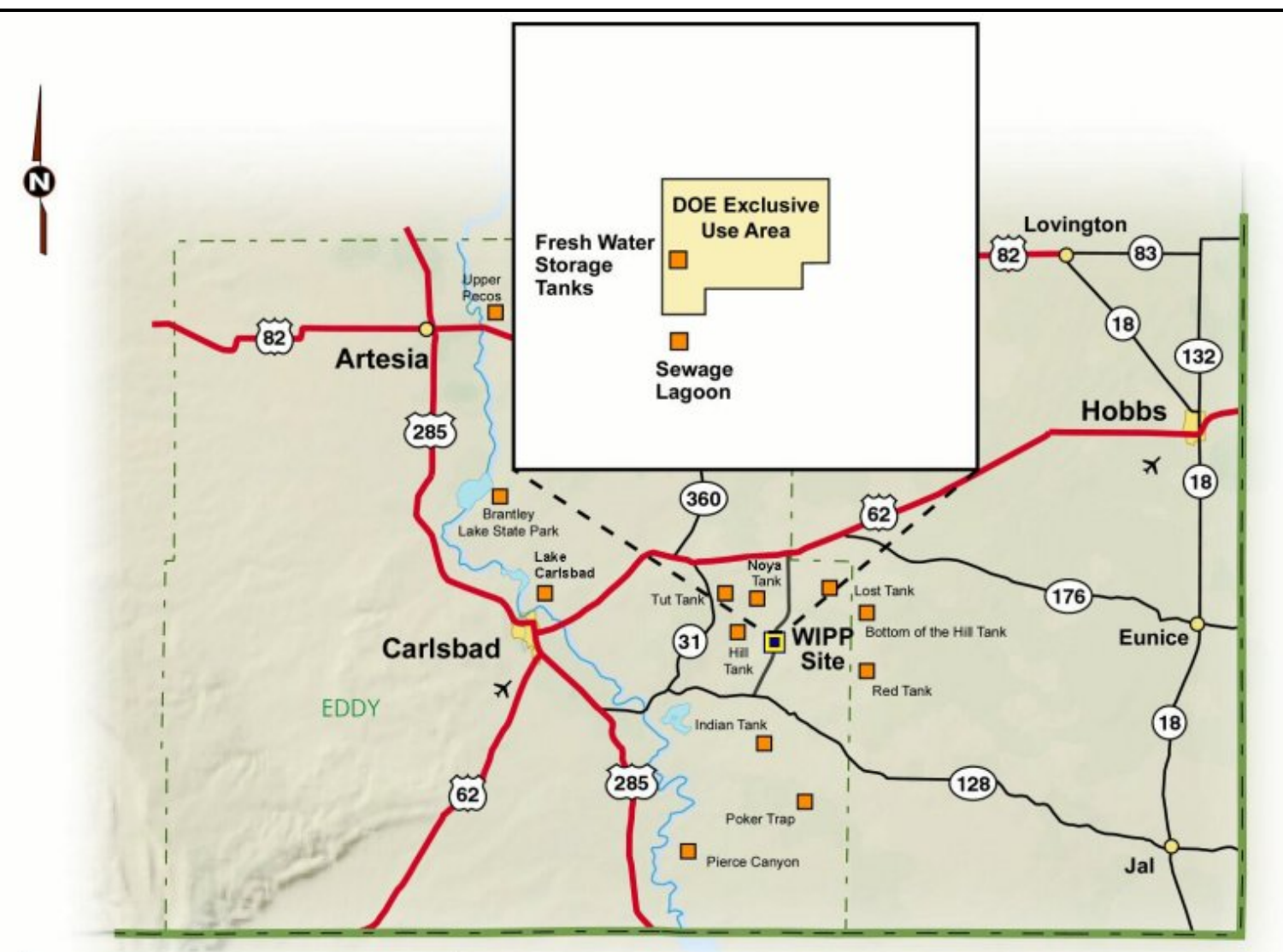

Radiological Surface Water Sampling Sites

Figure 5-3 - Surface Water Sampling Sites 


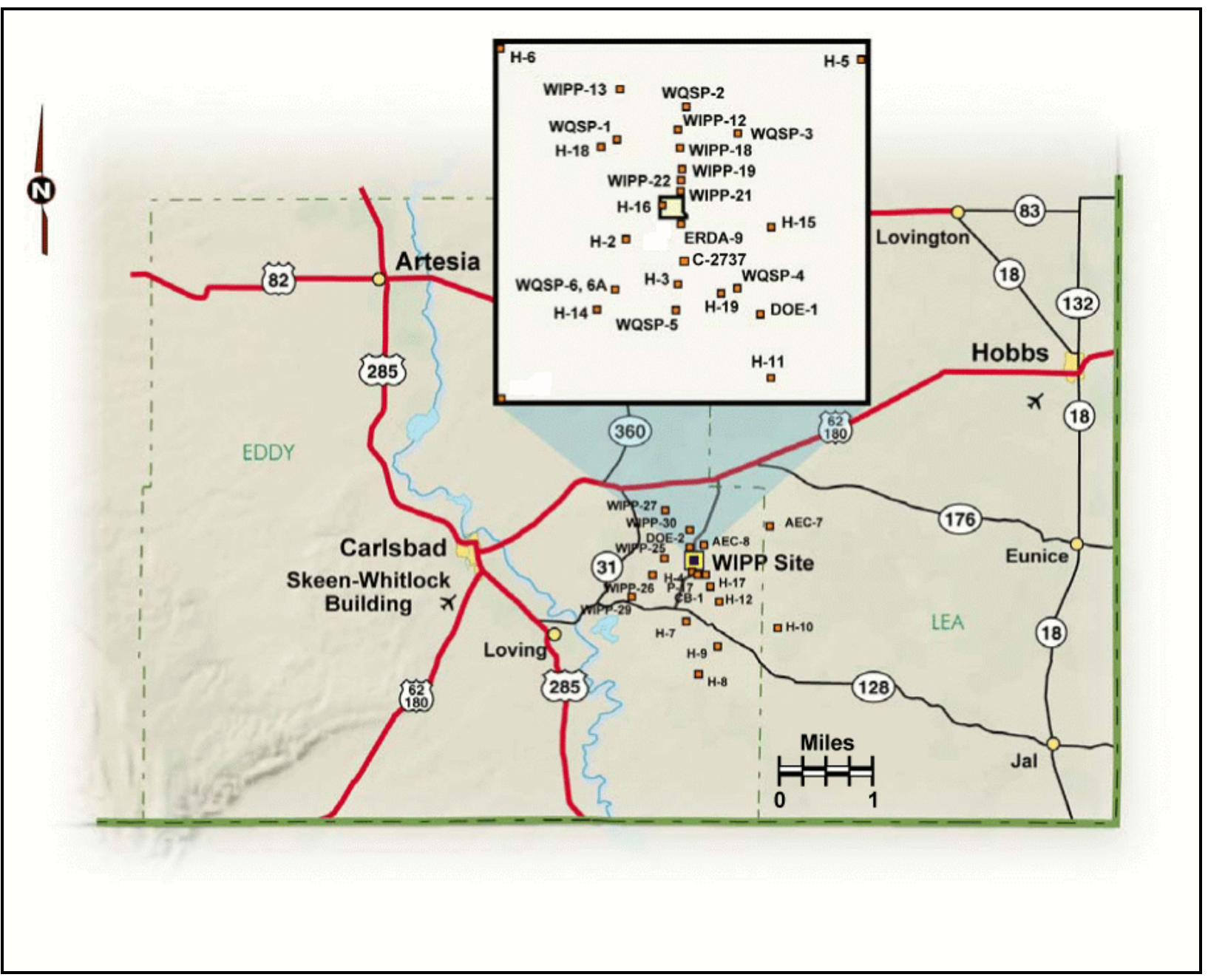

Figure 5-4 - Groundwater Level Surveillance Wells 


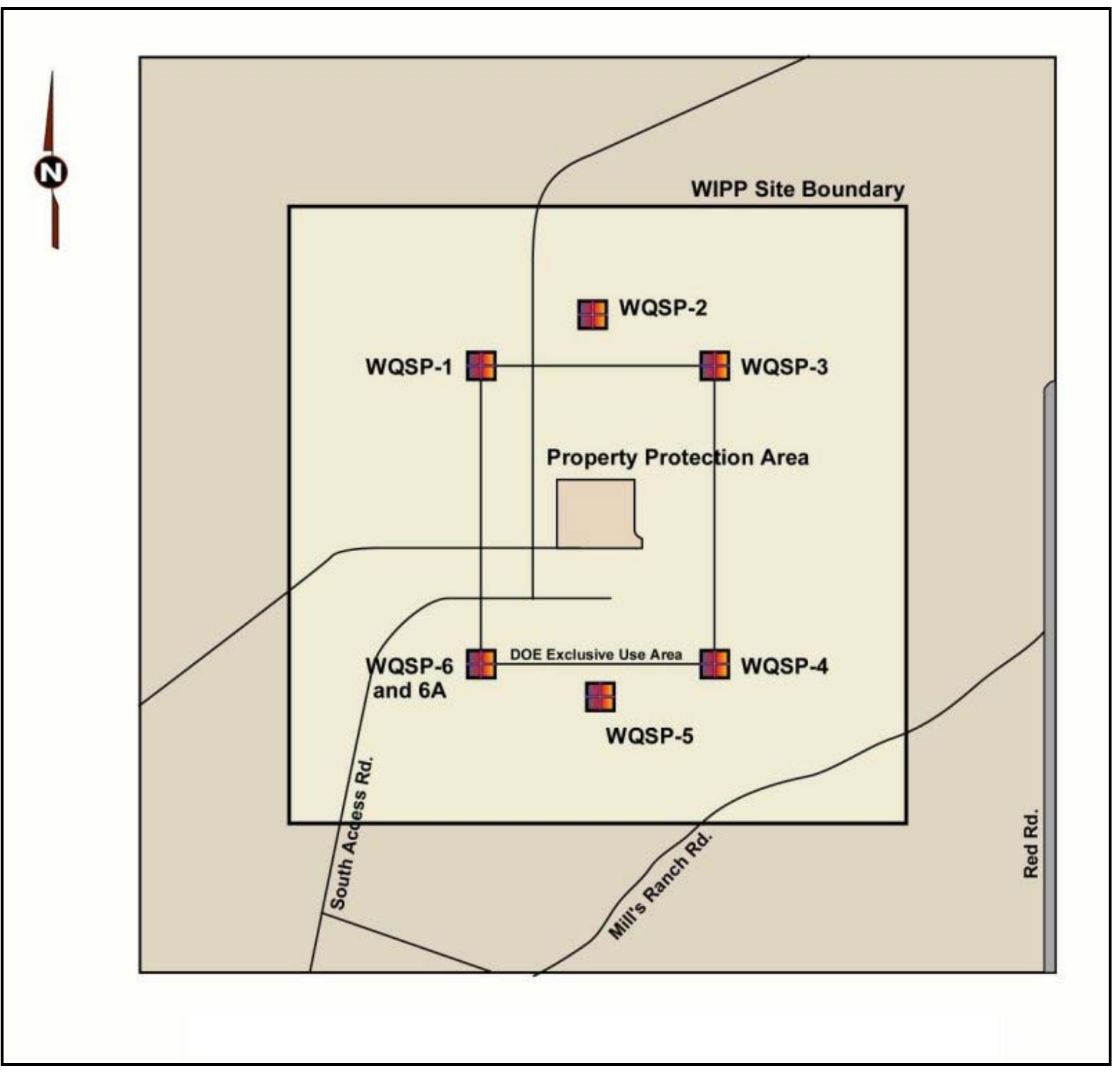

Figure 5-5 - Groundwater Sampling Locations 


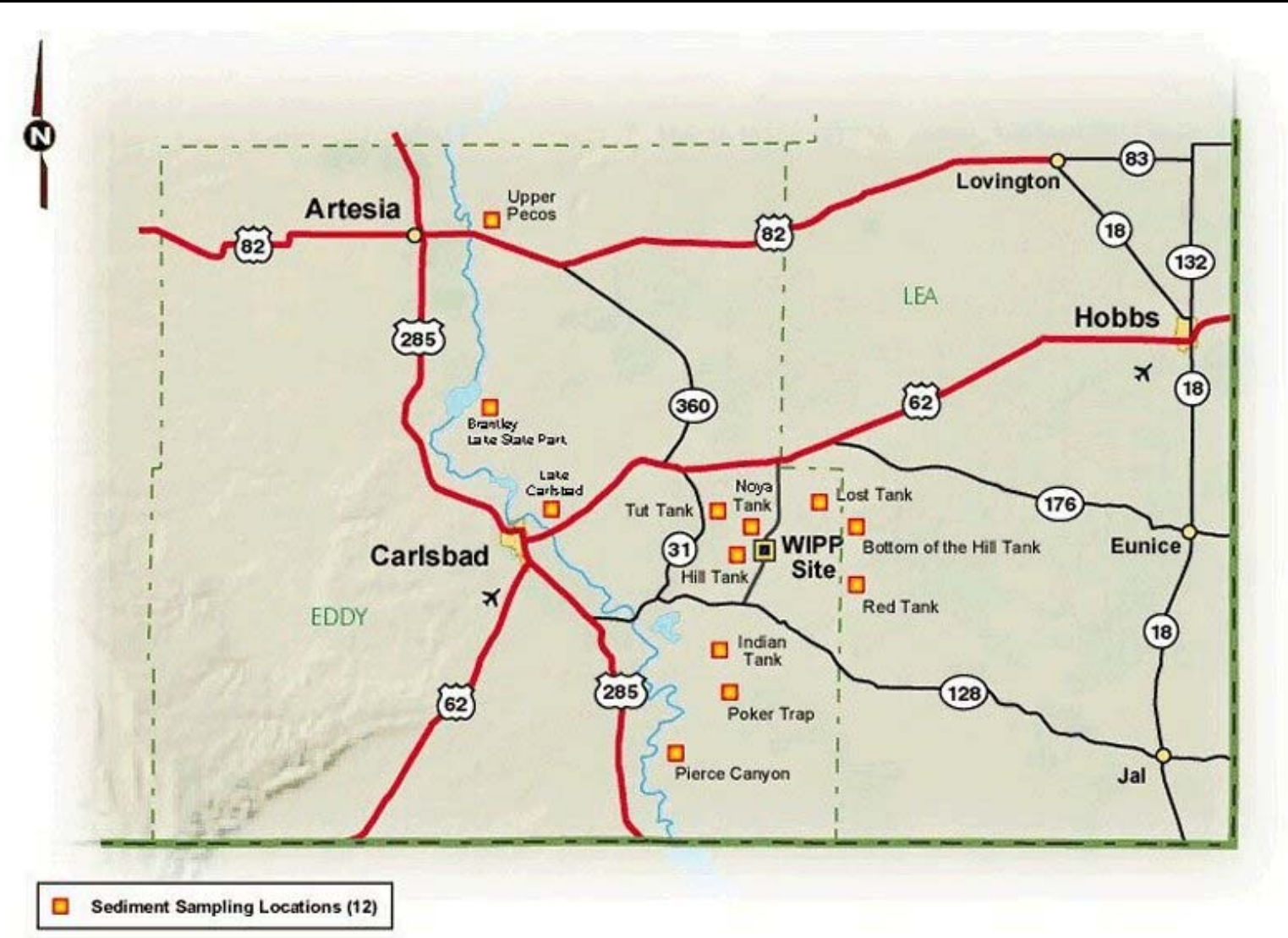

Figure 5-6 - Sediment Sampling Sites 


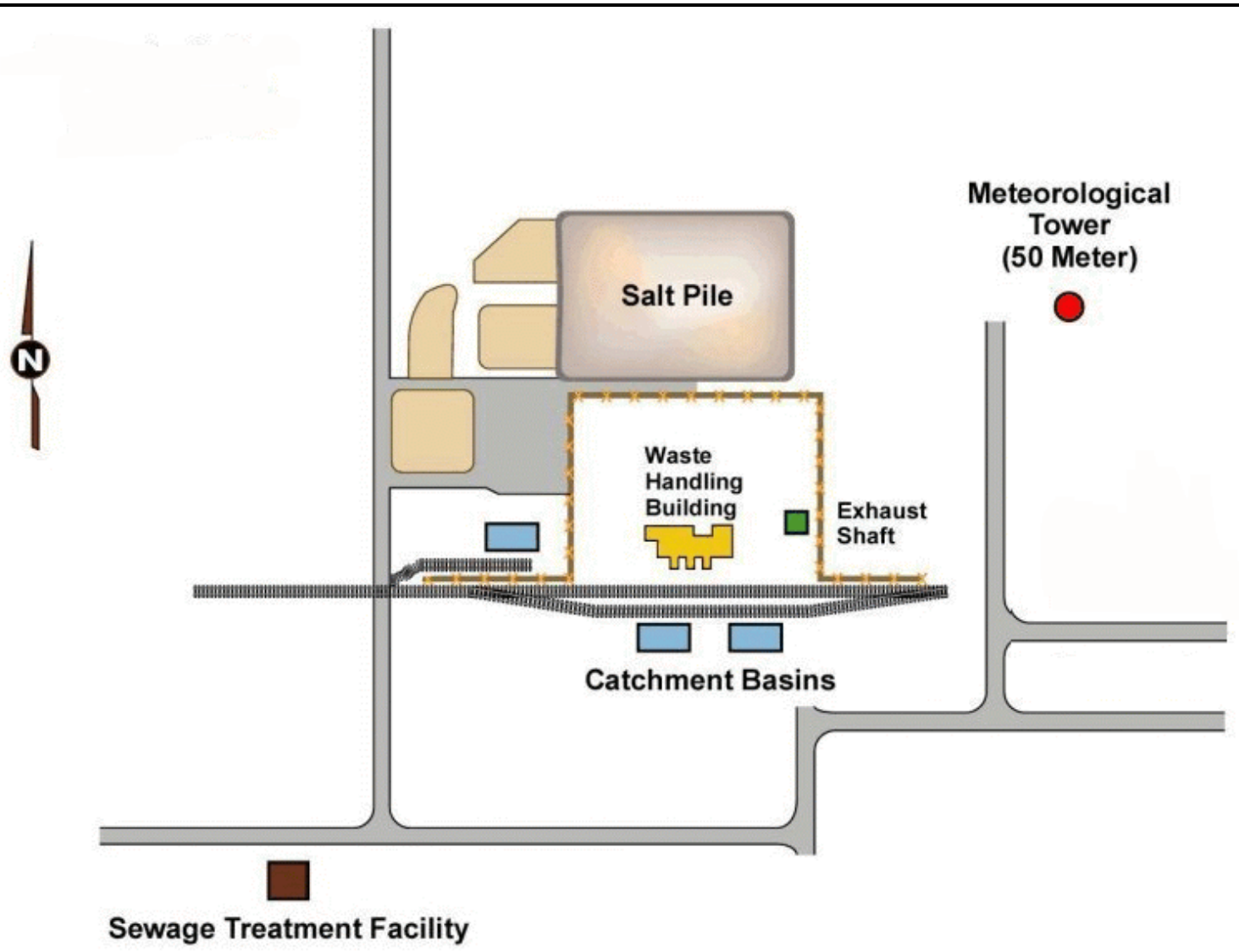

Figure 5-7 - Catchment Basins and Meteorological Monitoring Sites 


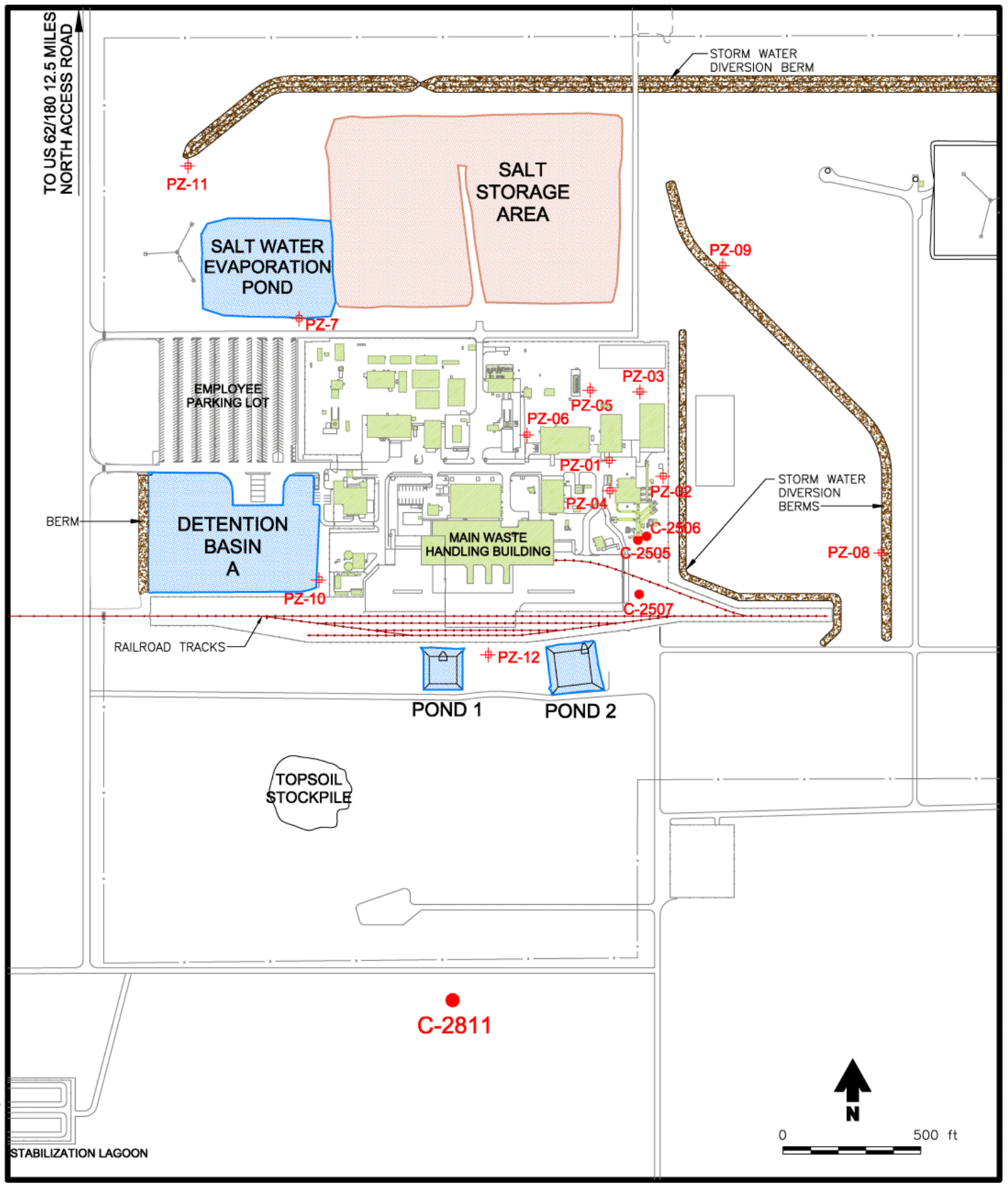

Figure 5-8 - Locations of SSW Wells (PZ-1 through PZ 12, C-2811, Wells C-2505, C-2506, and C-2507) 


\section{Waste Isolation Pilot Plant Environmental Monitoring Plan DOE/WIPP 99-2194, Rev. 2}

\subsection{DATA ANALYSES}

This section describes the criteria and methods used for statistically analyzing data collected in the environmental monitoring program. The goal of statistical data analyses is to provide an objective and reliable means for interpreting data in relation to the objectives of the data collection program. For the program, the principal goal is twofold: (1) to compile baseline data for historical comparison purposes and (2) to analyze for comparison to a data point or data set of equivalent data.

The data results of the sample media are graphed by analyte to evaluate analytical consistency presented in a time trend plot. This initial data evaluation process provides a method of evaluating data consistency and trends. Should a discrepancy be noted during this review, an in-depth evaluation can be performed to identify the source of the deviation (i.e., statistical outlier or analytical technique).

Analyses are required for each parameter before a statistically valid interpretation can be achieved. The type of analysis used varies among parameters due to the particular characteristics of parameters and the specific objectives of monitoring. Five general levels of data analyses are described here. Analyses at each of these levels is considered for each parameter. The levels are:

(1) Determination of accuracy for each point measurement by quantification and control of precision and bias.

(2) Evaluation of the effects of correlation on the expected value of the point measurement due to location and time of sampling.

(3) Identification of the appropriate model of variability (i.e., a probability density distribution) for each point measurement and the calculation of descriptive statistics based on the chosen model.

(4) Treatment of data anomalies.

(5) Interpretation of data through statistically valid comparisons (tests) and trend analysis.

Each of these levels of data analyses is described below and with the requirements for application to the EMP.

\subsection{Accuracy}

Accuracy is the closeness of a measurement to its actual, or true, value. Since the true value cannot be determined independently, accuracy cannot be absolutely determined. However, accuracy is controlled by two basic elements: bias (consistent over- or under-estimation of the true value) and precision (concentration of repeated measurements around a central [expected] value). Accuracy is maximized when bias is minimized and precision is maximized. 


\section{Waste Isolation Pilot Plant Environmental Monitoring Plan DOE/WIPP 99-2194, Rev. 2}

To some extent, precision and bias are controlled by strict adherence to sample collection, handling, and measurement protocols. Environmental Monitoring procedures specify the protocols for those functions performed at WIPP, and QC procedures establish control on precision and bias for contractors (see Section 7.0).

The remaining element of precision and bias is quantitatively estimated through periodic performance of the following measurements:

- Measurement of duplicate samples

- $\quad$ Repeated measurement of the same sample

- Measurement of blank samples

- Measurement of standard spiked samples (samples of an equivalent medium containing a known amount of the target species)

The measurement of duplicate samples is used for assessing precision incurred through the entire process of sample collection, handling, and measurement. Repeated measurements are used to determine the amount of imprecision attributable to measurement. Blanks are analyzed to monitor purity of reagents and any other crosscontamination attributing bias to the sample results during collection of samples and laboratory analysis. Contract laboratories performing WIPP sample analyses are required to participate in performance evaluation programs and pass the specific criteria set forth for measuring precision and accuracy.

The methods for satisfying these requirements will depend upon the sampling and measurement characteristics of each parameter. Generally, the following specifications will be followed:

- One duplicate sample is collected for each ten samples collected.

- $\quad$ One repeated measurement is made for each discrete set of samples analyzed, or for each tenth sample analyzed, whichever is more frequent.

- $\quad$ One blank sample is analyzed for each discrete set of samples analyzed (for radioactivity counts, the background count is not considered a blank).

- $\quad$ Measurements of spiked samples (Note: until WIPP has the capability to prepare or obtain spiked samples, WIPP will rely on the contract laboratory's in-house spike sample and recovery process.)

Variations from these specifications may be required due to peculiarities of the individual parameters and are stated in the analysis for that parameter. 


\section{Waste Isolation Pilot Plant Environmental Monitoring Plan DOE/WIPP 99-2194, Rev. 2}

\subsection{Temporal and Spatial Analysis}

Environmental parameters vary with space and time. The effect of one or both of these two factors on the expected value of a point measurement is statistically evaluated through spatial analysis and time series analysis; however, these methods often require extensive sampling efforts which are in excess of the practical requirements of the WIPP program. The application of these methods to a particular parameter must, therefore, be limited by consideration of its significance in the final interpretation of the data.

In particular, spatial analysis has limited use in this program, although the effect of spatial correlation on the interpretation of the data is considered for each parameter. Spatial variability is accounted for by the use of predetermined key sampling locations. Data analysis is performed on a location-specific basis, or data from different locations are combined only when the data are considered to be statistically homogeneous.

Time series analysis plays a more important role in data analysis for the EMP. Parameters are reported as time series, either in tabular form or plots. For key time series parameters, these plots are in the form of control charts on which control limits will be identified based on the preoperational database, fixed standards, control location databases, or other standards for comparison.

\subsection{Distributions and Descriptive Statistics}

Descriptive statistics are calculated for each homogeneous data set. At a minimum, these include a central value and a standard deviation. The central value is the mean of the data. The standard deviation is calculated and used as a basis for the reported range in variation. Typically, plus or minus two standard deviations from the mean are plotted on the graphs.

\subsection{Data Anomalies}

Historical or trend charts are maintained on all parameters and constituents for which analysis is performed. The charts and historical databases with established control limits at the 95 percent confidence level (or \pm 2 standard deviation from the mean) are used in identifying an outlier. The 95 percent confidence level means that 5 percent, or one out of 20 , normal results are expected to fall outside the limits. For analytical measurements reported as "nondetect" or below the method detection limit (MDL), the practical quantitation limit (which is between three and ten times the MDL) is set as the upper threshold. An investigation is prompted by reviewing the sampling process and verifying that the data quality objectives were met. The data are qualified accordingly and documented when the analytical results indicate matrix, method problems encountered during analysis, or an inconsistent sampling is identified. All analytical results are included in the charts, but excluded in establishing control limits if a known error has been identified. Including outliers in calculating control limits generates a range of values too broad or too small. 


\subsection{Data Comparisons}

Comparisons between data sets may be performed using standard statistical tests. The selection of the specific test is dependent upon the relative power of the test and the degree to which the underlying requirements of the test are met. In addition to tests comparing data from distinct locations and times, trend analyses may be performed on time series where sufficient data exist. A 95 percent confidence level will be used for the final interpretation of results.

\subsection{Laboratory Procedures}

Environmental sampling and analytical laboratory procedures used to obtain quality results for WIPP are contained and/or described in the following documents:

- $\quad$ WIPP Groundwater Monitoring Program Plan (WP 02-1)

- $\quad$ The environmental monitoring procedures of the WP 02-EM series

- $\quad$ Radiochemistry Quality Assurance Plan (WP 12-RL.01)

- Washington TRU Solutions LLC Quality Assurance Program Description (WP 13-1)

WIPP has analytical capabilities as well as subcontracted analytical support. Each laboratory is responsible for maintaining an approved QA program for each of the programs discussed in Section 5.0.

\subsection{Sample Handling}

\section{Sample Identification and Tracking}

There is a sample identity code used to uniquely identify environmental samples collected. The code contains sample-specific information used to accurately identify sample type, sample location, date, and sequence of sampling event. A detailed description of the sample identification for radiological and nonradiological samples, including sample identification, calculations, computer inputs, and other applicable reviews, are described in environmental sampling procedures. Field data sheets are also maintained in accordance with procedures. The sample tracking is performed from "cradle to grave."

\section{Sampling Schedule}

The sample type, location, and frequency of collection are noted in Table 5-1. The sampling schedule at WIPP is based on waste composition, climate, and demography. 


\section{Waste Isolation Pilot Plant Environmental Monitoring Plan \\ DOE/WIPP 99-2194, Rev. 2}

\section{Environmental Activity Levels}

During operations, all TRU wastes will remain in sealed containers. Therefore, radionuclide levels in environmental samples are expected to remain minute during operations. All environmental samples are collected in accordance with accepted practices and widely recognized methodologies and criteria for environmental monitoring (e.g., the environmental monitoring procedures of the WP 02-EM series).

\section{Packaging and Shipping of Samples Off-Site}

Environmental samples sent off-site for analysis are packaged and shipped in accordance with transportation regulations and specific sampling procedures (i.e., soil, water, vegetation, etc.) listed in the environmental monitoring procedures of the WP 02-EM series. These procedures outline the chain-of-custody requirements that ensure the integrity of samples. WIPP does not handle high-activity samples in the environmental monitoring programs. Contract laboratories are required to follow QA/QC procedures to ensure that cross-contamination between high and low activity samples will not occur.

The laboratory must be approved through a WTS evaluation to be put on the WTS qualified supplier list before proceeding with strict QA laboratory evaluations. The quality of the data from analytical contract laboratories is verified by (1) participation in interlaboratory cross-checks, (2) duplicate and blank sample analysis, and (3) occasional comparison of results from sample splits that are provided to stakeholders. 
THIS PAGE INTENTIONALLY LEFT BLANK 


\section{Waste Isolation Pilot Plant Environmental Monitoring Plan \\ DOE/WIPP 99-2194, Rev. 2}

\subsection{QUALITY ASSURANCE}

This section defines the policies and procedures that have been implemented at WIPP to provide confidence in the quality of the environmental data that are generated. QA practices that cover monitoring activities at WIPP are consistent with applicable elements of the 18-element format in ANSI/ASME [American National Standards Institute/American Society of Mechanical Engineers] NQA-I [Nuclear Quality Assurance] (ANSI, 1989).

WP 13-1 (WTS QAPD) defines QA requirements and responsibilities that apply to WTS. The format of the QAPD is based on the QA criteria of 10 CFR $\$ 830.120$. Because QA requirements of data collection for compliance with environmental regulations are less detailed than those usually applied to nuclear facilities, the WTS QAPD also addresses EPA QA requirements extracted from the EPA's QAMS-005/80, Interim Guidelines and Specifications for Preparing Quality Assurance Project Plans (EPA, 1983). For the WIPP Project, these EPA QA requirements apply to environmental data operations (EDOs); that is, compliance activities associated with collection and analysis of environmental samples, including data reduction, handling, reporting, and records management. Examples of EDOs at WIPP include the National Emission Standards for Hazardous Air Pollutants and RCRA hazardous waste characterization. Table 7-1 demonstrates the relationship between QA requirements from 10 CFR $\$ 830.120$, ANSI/ASME NQA-1, and EPA QAMS-005/80.

A comprehensive QA program has been implemented to ensure that the data collected are representative of actual concentrations in the environment. Each contract laboratory is responsible for maintaining an approved QA program detailing the following:

- $\quad$ Routine calibration of instruments

- $\quad$ Frequent source and background checks (as appropriate)

- Routine yield determinations of radiochemical procedures

- Replicate/duplicate analyses to check precision

- $\quad$ Standard and spike analyses to check accuracy

- Expiration of reagents to ensure that chemical purity, which could affect the results of the analytical process, is not compromised

The accuracy of chemical or radiochemistry analysis is ensured through the use of standards traceable to the National Institute of Standards and Technology and participation in a performance evaluation program. 


\subsection{Goal}

The WTS QA policy sets a goal to perform all work in such a manner that the required quality is attained or exceeded. To attain this goal, WTS has developed and implemented a formal QA program that is tailored for activities associated with receipt of TRU waste, including operational safety, environmental compliance, and performance assessment.

Table 7-1 - Title 10 CFR $\$ 830.120$ Cross-Reference to ANSI/ASME NQA-1 and EPA QAMS-005/80

\begin{tabular}{|c|c|c|c|}
\hline \multicolumn{2}{|c|}{10 CFR $\S 830.120$} & $\begin{array}{c}\text { ANSI/ASME NQA-1 BASIC } \\
\text { REQUIREMENT }\end{array}$ & $\begin{array}{c}\text { EPA QAMS-005/80 } \\
\text { ELEMENT }\end{array}$ \\
\hline \multirow{4}{*}{$\begin{array}{c}M \\
\mathbf{A} \\
\mathbf{N} \\
\mathbf{A} \\
\mathbf{G} \\
\mathrm{E} \\
\mathrm{M} \\
\mathrm{E} \\
\mathbf{N} \\
\mathbf{T}\end{array}$} & 1. Program & $\begin{array}{l}\text { 1. Organization } \\
\text { 2. Quality Assurance Program }\end{array}$ & $\begin{array}{l}\text { 3. Project Description } \\
\text { 4. Project Organization \& Responsibility } \\
\text { 16. Quality Assurance Reports to } \\
\text { Management }\end{array}$ \\
\hline & 2. Personnel Training and Qualification & 2. Quality Assurance Program & $\begin{array}{l}\text { 3. Project Description } \\
\text { 16. Quality Assurance Reports to } \\
\text { Management }\end{array}$ \\
\hline & 3. Quality Improvement & $\begin{array}{l}\text { 15. Control of Nonconforming Items } \\
\text { 16. Corrective Action }\end{array}$ & 15. Corrective Action \\
\hline & 4. Documents and Records & $\begin{array}{l}\text { 6. Document Control } \\
\text { 17. Quality Assurance Records }\end{array}$ & $\begin{array}{l}\text { 1. Title Page } \\
\text { 2. Table of Contents }\end{array}$ \\
\hline \multirow{4}{*}{$\begin{array}{l}P \\
E \\
R \\
F \\
O \\
R \\
M \\
A \\
N \\
C \\
E\end{array}$} & 5. Work Processes & $\begin{array}{l}\text { 5. Instructions, Procedures, and Drawings } \\
\text { 8. Identification and Control of Items } \\
\text { 9. Control of Processes } \\
\text { 12. Control of Measuring and Test Equipment } \\
\text { 13. Handling, Storage, and Shipping }\end{array}$ & $\begin{array}{l}\text { 6. Sampling Procedures } \\
\text { 7. Sample Custody } \\
\text { 8. Calibration } \\
\text { 9. Analytical Procedures } \\
\text { 13. Preventive Maintenance }\end{array}$ \\
\hline & 6. Design & 3. Design Control & $\begin{array}{l}\text { 5. Data Quality Objectives } \\
\text { 6. Sampling Procedures } \\
\text { 10. Data Reduction } \\
\text { 11. Internal Quality Control } \\
\text { 14. Routine Procedures to Assess Data } \\
\text { Quality }\end{array}$ \\
\hline & 7. Procurement & $\begin{array}{l}\text { 4. Procurement Document Control } \\
\text { 7. Control of Purchased Items and Services }\end{array}$ & $\mathrm{N} / \mathrm{A}$ \\
\hline & 8. Inspection and Acceptance Testing & $\begin{array}{l}\text { 10. Inspection } \\
\text { 11. Test Control } \\
\text { 12. Control of Measuring and Test Equipment } \\
\text { 14. Inspection, Test and Operating Status }\end{array}$ & $\begin{array}{l}\text { 8. Calibration } \\
\text { 13. Preventive Maintenance }\end{array}$ \\
\hline \multirow[t]{2}{*}{$\begin{array}{l}A \\
S \\
S \\
E \\
S \\
S\end{array}$} & 9. Management Assessment & 2. Quality Assurance Program & $\begin{array}{l}\text { 3. Project Description } \\
\text { 12. Audits } \\
\text { 14. Routine Procedures to Assess Data } \\
\text { Quality } \\
\text { 16. Quality Assurance Reports to } \\
\text { Management }\end{array}$ \\
\hline & 10. Independent Assessment & 18. Audits & $\begin{array}{l}\text { 14. Routine Procedures to Assess Data } \\
\text { Quality }\end{array}$ \\
\hline
\end{tabular}




\section{Waste Isolation Pilot Plant Environmental Monitoring Plan DOE/WIPP 99-2194, Rev. 2}

\subsection{Program Elements/Criteria}

The specific WIPP QA program elements/criteria that are applicable to the EMP are listed above by 10 CFR $\$ 830.120$ criterion. These elements establish the applicable QA requirements that are required for compliance activities associated with the collection and analysis of environmental samples, including data reduction, handling, reporting, and records management.

\subsubsection{Program}

This element encompasses programmatic practices and procedures that include quality assurance project plans (QAPjPs) for EDOs that consider and address the 16 essential elements described in Section 5 of the EPA QAMS-005/80. Project descriptions for specific EDOs are provided in project-specific QAPjPs. These project-specific QAPjPs include explanations for exclusion of any of the 16 elements that would not be relevant to a specific project. The project descriptions include an experiment design description in sufficient detail for stand-alone review and approval of the plan. EDO project descriptions incorporate the following elements, as appropriate:

- $\quad$ Flow diagrams, tables, and charts

- Dates anticipated for start and completion

- Intended end use of acquired data

Each WIPP organization involved with activities and operations affecting environmental data quality will specify QA/QC responsibilities in departmental or project-specific QAPjPs. The QAPjPs include tables or charts showing the project organization and line authority. Key individuals, including the designated QA officer, who are responsible for ensuring the collection of valid data and the routine assessment of measurement systems for precision and accuracy, are listed.

Precision and accuracy of all environmental monitoring data are routinely assessed and reported. Project-specific QAPjPs associated with EDOs provide the mechanism for periodic reports to the DOE WIPP Project management on the performance of measurement systems and data quality. These reports include:

- $\quad$ Periodic assessment of measurement data accuracy, precision, and completeness

- Results of performance audits

- $\quad$ Results of system audits

- $\quad$ Significant QA problems which, if uncorrected, could have a serious effect on the health and safety of WIPP workers and the public, seriously impact the operation of WIPP, or have a noticeable adverse impact on the environment 


\section{Waste Isolation Pilot Plant Environmental Monitoring Plan DOE/WIPP 99-2194, Rev. 2}

- $\quad$ Recommended corrective actions

- Identification of individuals responsible for report preparation

- $\quad$ Provisions in the final report for a separate QA section that summarizes data quality information contained in the periodic reports

\subsubsection{Personnel Training and Qualification}

The WIPP training program has been designed to ensure that personnel performing work are capable of performing their assigned task proficiently. Personnel who perform work that requires special skills or abilities are required to meet the qualification requirements for that specific task unless directly supervised by a qualified person.

\subsubsection{Quality Improvement}

The quality improvement process has been established and implemented to improve quality and provide corrective action procedures. Corrective action and nonconformance procedures for activities associated with environmental data collection are identified in project-specific QAPjPs. At a minimum, the following elements are addressed:

- $\quad$ Predetermined limits for data acceptability beyond which corrective action is required

- $\quad$ Process for tracking, verification, and closeout

- Identification of individuals responsible for initiating corrective action and individuals responsible for verifying and approving implementation of the corrective action

Corrective action may be initiated through routine operations, performance audits, system audits, inter/intralaboratory comparison studies, or performance demonstrations conducted by the DOE Carlsbad Field Office.

\subsubsection{Documents and Records}

Procedures are established that control the preparation, review, approval, issuance, use, and revision of documents that establish policies, prescribe work, specify requirements, establish design, or that are being used for the performance of quality-related activities. Each project-specific QA implementation plan for EDOs includes documentation of approval in the form of a signature page.

Procedures are also in place to ensure that records are specified, prepared, reviewed, approved, and maintained to accurately reflect completed work. This process is described in WP 15-PR, WIPP Records Management Program. The WIPP records management program provides a project wide records management system that 


\section{Waste Isolation Pilot Plant Environmental Monitoring Plan DOE/WIPP 99-2194, Rev. 2}

coordinates the collection, maintenance, identification, and preservation of WIPP Project records.

Records generated through environmental monitoring activities are controlled and maintained in accordance with WP 15-PR. This plan interprets and implements the records management requirements contained in DOE/CAO 94-1001, Carlsbad Area Office Information Management Plan (DOE, 1994). The requirements stated in this plan apply to all WTS organizations. The plan provides the interpretations and the guidance necessary to meet the records management requirements for the creation, maintenance, use, and disposition of records that document and support the WIPP mission.

\subsection{Reporting}

The WIPP EMP is reviewed annually and updated at least every three years. Changes are made as new regulations are promulgated which specify record-keeping, reporting, and other programmatic requirements applicable to the environmental monitoring program at WIPP.

The WIPP SER (DOE, 2003a) is prepared according to DOE Order 231.1A (DOE, 2003b). This report summarizes the facility's compliance with applicable environmental regulations and informs the public about the impact of WIPP operations on the surrounding environment.

The EPA has promulgated environmental standards for the management and disposal of TRU radioactive wastes under the authority of the EPA and the Nuclear Waste Policy Act. The EPA has not specified reporting requirements applicable to WIPP under this regulation.

The Office of Management and Budget (OMB) Circular A-106, Reporting Requirements in Connection with the Prevention, Control, and Abatement of Environmental Pollution at Existing Federal Facilities (OMB, 1975), has established a semiannual reporting requirement for implementing Sections 1 through 4 of Presidential Executive Order 12088 and Presidential Executive Order 11752 pertaining to the control of environmental pollution from existing federal facilities. The plans, to be submitted on December 31 and June 30, identify projects necessary to bring federal facilities into compliance with applicable environmental standards.

The following documents, regulations and laws contain the reporting requirements applicable to WTS's environmental monitoring program:

- $\quad$ Hazardous Waste Facility Permit (NMED 1999)

- $\quad$ Land Withdrawal Act (LWA) and LWA amendments (Public Laws 102-579 and 104-201)

- $\quad$ DOE Order 5400.5 (DOE, 1990) 


\section{Waste Isolation Pilot Plant Environmental Monitoring Plan DOE/WIPP 99-2194, Rev. 2}

- $\quad$ DOE Order 231.1A (DOE, 2003b)

- $\quad$ Clean Air Act (42 United States Code [U.S.C.] 185h-h-7)

- $\quad$ Clean Water Act (33 U.S.C. 1251)

- $\quad$ Superfund Amendments and Reauthorization Act - Title 3 (42 U.S.C. 9601)

- $\quad$ Resource Conservation and Recovery Act (10 CFR §600.149)

- $\quad$ Comprehensive Environmental Response, Compensation, and Liability Act Program (DOE, 1985)

- $\quad$ OMB Circular A-106 (OMB, 1975)

- $\quad 40$ CFR Parts 191/194

- DOE/EH-0173T (guidance document) (DOE, 1991), as applicable for routine environmental monitoring

- $\quad$ 20.4.1 NMAC

Thorough reporting and record keeping will be performed at WTS as essential elements of complying with state and federal regulations.

Complete, accurate, and auditable environmental monitoring program records will be maintained. The WTS records inventory and disposition schedule will govern environmental monitoring records management.

\subsubsection{Work Processes}

Work is performed to established technical standards and administrative controls. For each major measurement parameter, the design of sampling methodology, equipment, and procedures are documented and approved. The following requirements for sample design are addressed in project-specific technical and/or QA plans, as applicable:

- Description of techniques or guidelines used to select sampling sites

- Inclusion of specific sampling procedures to be used, either by reference in the case of approved standard operating procedures (SOPs), or in entirety if the procedures are nonstandard

- Charts, flow diagrams, or tables delineating sampling program operations

- A description of containers, procedures, reagents, etc., used for sample collection, preservation, transportation, and storage 


\section{Waste Isolation Pilot Plant Environmental Monitoring Plan \\ DOE/WIPP 99-2194, Rev. 2}

- $\quad$ Special conditions for the preparation of sampling equipment and containers to avoid sample contamination

- $\quad$ Sample preservation methods and holding times

- Time considerations for shipment of samples to the laboratory

- Sample custody or chain-of-custody procedures

- Forms, notebooks, databases, and procedures to be used to document sample history, sampling conditions, and required analyses

Samples collected for environmental compliance activities or for site validation are controlled by approved chain-of-custody procedures. The actual practices used are documented in project-specific QA implementation plans. The following sample custody procedures are specified in the QAPJP:

- $\quad$ For field sampling operations:

- $\quad$ Documentation of procedures for preparation of reagents or supplies which become an integral part of the sample

- $\quad$ Procedures and forms for recording the exact location and specific considerations associated with sample acquisition

- $\quad$ Documentation of specific sample preservation methods

- $\quad$ Sample labels containing all information necessary for effective sample tracking

- $\quad$ For laboratory operations:

- $\quad$ Identification of responsible party to act as sample custodian at the laboratory facility authorized to sign for incoming field samples, to obtain documents of shipment, and to verify the data entered onto the same custody records

- $\quad$ A laboratory sample custody log consisting of serially numbered standard lab-tracking report sheets

- $\quad$ Specification of laboratory sample custody procedures for sample handling, storage, and disbursement for analysis

Custody records are treated as permanent QA records by the recipient upon final transmission of the analytical data. 


\section{Waste Isolation Pilot Plant Environmental Monitoring Plan \\ DOE/WIPP 99-2194, Rev. 2}

Calibration procedures and frequency for EDO activities are specified in project-specific QA implementation plans. The plans include:

- A reference to the applicable SOP, or written description of the calibration procedures used for each major measurement parameter

- $\quad$ Frequency of calibration

- Calibration standards to be used, as well as their sources and traceability

Preventive maintenance of equipment used for collection and measurement of environmental data is identified in project-specific QA implementation plans. The following types of preventive maintenance items are addressed:

- A schedule for preventive maintenance tasks

- A list of critical spare parts that should be available

Procedures used for controlling the analysis of samples collected for EDO activities are specified in project-specific QA implementation or technical plans. For each measurement parameter the applicable procedure is either described in writing or referenced as a SOP.

\subsubsection{Design}

For each major measurement parameter, the design of sampling methodology, equipment, and procedures are documented and approved. The following requirements for sample design are addressed in project-specific plans and/or QA plans:

- Description of techniques or guidelines used to select sampling sites

- Inclusion of specific sampling procedures to be used, either by reference in the case of approved SOPs or in it's entirety if the procedures are nonstandard

- $\quad$ Charts, flow diagrams, or tables delineating sampling program operations

- Description of containers, procedures, reagents, etc., used for sample collection, preservation, transport, and storage

- $\quad$ Special conditions for the preparation of sampling equipment and containers to avoid sample contamination

- Sample preservation methods and holding times

- Time considerations for shipment of samples to the laboratory

- $\quad$ Sample custody or chain-of-custody procedures 


\section{Waste Isolation Pilot Plant Environmental Monitoring Plan \\ DOE/WIPP 99-2194, Rev. 2}

- $\quad$ Forms, notebooks, databases, and procedures to be used to document sample history, sampling conditions, and required analyses

\subsubsection{Procurement}

The control of procurement documents ensures that procured items and services meet established requirements and specifications. Basic procurement requirements include:

- $\quad$ Applicable design specifications and other order requirements are referenced in documents for procurement of items and services.

- $\quad$ Supplier has a QA program consistent with applicable requirements.

- $\quad$ Procurement actions be performed in accordance with written procedures that describe the actions involved in the preparation, review, approval, control, and changes of procurement documents.

\subsubsection{Inspection and Acceptance Testing}

Inspection and acceptance testing of specified items and processes are conducted using established acceptance and performance criteria.

Equipment used for inspections and tests are calibrated and maintained. Calibration procedures and frequency for EDO activities are specified in project-specific QA implementation plans. These plans will include:

- $\quad$ A reference to the applicable SOP, or written descriptions of the calibration procedures used for each major measurement parameter

- $\quad$ Frequency of calibration

- $\quad$ Calibration standards to be used, as well as their sources and traceability

\subsubsection{Management Assessment}

Senior management assembles input from the following sources to form the basis of management assessment:

- $\quad$ Line management's self-assessment reports

- $\quad$ Independent assessment reports

- $\quad$ Corrective action reports, including conditions adverse to quality, nonconformance reports, program deficiency reports, audit reports, and requests for corrective action. 
Following the assessment, the effectiveness of the QA program is documented. Further, areas for quality improvement root cause analysis (for significant nonconformances or high-risk items/activities), preventive or corrective actions, milestones for completion, responsibility assignments, trend analysis, and lessons learned are documented and transmitted to the DOE.

\subsubsection{Independent Assessment}

Independent assessments are performed to verify procedure compliance and are also used to prove independent oversight of the self-assessment process performed by line management. Independent assessments focus on improving items and processes by emphasizing line organization's achievement of quality. Results from independent assessments are transmitted to senior management as input for determining the effectiveness of the integrated QA program. In this regard, personnel performing independent assessments act in a management advisory function. 


\section{Waste Isolation Pilot Plant Environmental Monitoring Plan \\ DOE/WIPP 99-2194, Rev. 2}

\subsection{REFERENCES}

10 CFR §830.120. Quality Assurance Requirements. Code of Federal Regulations, Washington, D.C., Office of the Federal Register, National Archives and Records Administration.

10 CFR Part 834. Radiation Protection of the Public and Environment. (Draft). Code of Federal Regulations, Washington, D.C., Office of the Federal Register, National Archives and Records Administration.

29 CFR \$1910.1000. Occupational Safety and Health Standards: Air Contaminants. Code of Federal Regulations, Washington, D.C., Office of the Federal Register, National Archives and Records Administration.

40 CFR Part 61, Subpart H. National Emissions Standards for Emissions of Radionuclides Other Than Radon From Department of Energy Facilities, Washington, D.C., Office of the Federal Register, National Archives and Records Administration.

40 CFR Part 191. Environmental Radiation Protection Standards for Management and Disposal of Spent Nuclear Fuel, High-level and Transuranic Radioactive Wastes. Code of Federal Regulations, Washington, D.C., Office of the Federal Register, National Archives and Records Administration.

40 CFR Part 194. Criteria for the Certification and Recertification of the Waste Isolation Pilot Plant's Compliance with the 40 CFR Part 191 Disposal Regulations. Code of Federal Regulations, Washington, D.C., Office of the Federal Register, National Archives and Records Administration.

40 CFR Part 264. Standards for Owners and Operators of Hazardous Waste Treatment, Storage, and Disposal Facilities. Code of Federal Regulations, Washington, DC, Office of the Federal Register National Archives and Records Administration.

38 FR 34793. Presidential Executive Order 11752, Prevention, Control, and Abatement of Environmental Pollution at Federal Facilities. December 19, 1973.

43 FR 47707. Presidential Executive Order 12088, Federal Compliance with Pollution Control Standards. October 13, 1978.

20.4.1 NMAC. Title 20, New Mexico Administrative Code, Santa Fe, New Mexico.

33 U.S.C. 1251, et seq. Clean Water Act.

42 U.S.C. 185h-h-7, et seq. Clean Air Act.

42 U.S.C. §6901, et. seq. Resource Conservation and Recovery Act (RCRA). 


\section{Waste Isolation Pilot Plant Environmental Monitoring Plan \\ DOE/WIPP 99-2194, Rev. 2}

42 U.S.C. 9601 et seq. Superfund Amendments and Reauthorization Act. Title III. Emergency Planning and Community Right-to-Know Act (42 U.S.C. 11001 et seq.).

ANSI, 1989. Quality Assurance Program Requirements for Nuclear Facilities. ANSI/ASME NQA-1, 1989 Edition.

Corley, J. P., D. H. Denham, R. E. Jaguish, D. E. Michels, A. R. Olsen, and D. A. Waite, 1981. A Guide for Environmental Radiological Surveillance at U.S. Department of Energy Installations. DOE/EP-0023, Washington, D.C., U.S. Department of Energy.

DOE, 1980. Final Environmental Impact Statement, Waste Isolation Pilot Plant. DOE/EIS-0026, Vols. 1 and 2, Washington, D.C., U.S. Department of Energy.

DOE, 1985. Comprehensive Environmental Response, Compensation and Liability Act Program, DOE Order 5480.14, Washington, D.C.

DOE, 1988a. External Dose Rate Conversion Factors for Calculations of Dose to the Public. DOE/EH-0070. Washington, D.C., U.S. Department of Energy.

DOE, 1988b. Internal Dose Conversion Factors for Calculations of Dose to the Public. DOE/EH-0071. Washington, D.C., U.S. Department of Energy.

DOE, 1989. Operational Environmental Monitoring Plan for the Waste Isolation Pilot Plant. DOE/WIPP 88-025. Carlsbad, New Mexico, Waste Isolation Pilot Plant, U.S. Department of Energy.

DOE, 1990. Radiation Protection of the Public and the Environment, DOE Order 5400.5, Washington, D.C.

DOE, 1991. Environmental Regulatory Guide for Radiological Effluent Monitoring and Environmental Surveillance. DOE/EH-0173T. Washington, D.C.

DOE, 1992a. Statistical Summary of the Radiological Baseline for the WIPP. DOE/WIPP 92-037. Carlsbad, New Mexico, Waste Isolation Pilot Plant, U.S. Department of Energy.

DOE, 1992b. Summary of the Salt Impact Studies at the WIPP, 1984 to 1990. DOE/WIPP 92-038. Carlsbad, New Mexico, Waste Isolation Pilot Plant, U.S. Department of Energy.

DOE, 1992c. A Study of Disturbed Land Reclamation Techniques for the WIPP. DOE/WIPP 92-039. Carlsbad, New Mexico, Waste Isolation Pilot Plant, U.S. Department of Energy. 


\section{Waste Isolation Pilot Plant Environmental Monitoring Plan DOE/WIPP 99-2194, Rev. 2}

DOE, 1992d. Background Water Quality Characterization Report for the WIPP. DOE/WIPP 92-013. Carlsbad, New Mexico, Waste Isolation Pilot Plant, U.S. Department of Energy.

DOE, 1994. Information Management Plan. CAO-94-1001, Revision 1. Carlsbad, New Mexico, Carlsbad Area Office, U.S. Department of Energy.

DOE 1996. Title 40 CFR Part 191 Compliance Certification Application. DOE/CAO-1996-2184. Carlsbad, New Mexico, Carlsbad Field Office, U.S. Department of Energy.

DOE, 1997a. Waste Isolation Pilot Plant Safety Analysis Report. DOE/WIPP-95-2065, Revision 3. Carlsbad, New Mexico, Waste Isolation Pilot Plant, U.S. Department of Energy.

DOE, 1997b. Environmental Measurement Laboratory Procedures Manual. HASL-300, $28^{\text {th }}$ edition. New York, N.Y., U.S. Department of Energy.

DOE, 2002. Geotechnical Analysis Report for July 2000 - June 2001, DOE/WIPP 02-3177. Volume 1. September 2002.

DOE, 2003a. Waste Isolation Pilot Plant Site Environmental Report Calendar Year 2002. DOE/WIPP 98-2225. Carlsbad, New Mexico, Waste Isolation Pilot Plant, U.S. Department of Energy.

DOE, 2003b. Environment, Safety and Health Reporting. DOE Order 231.1A. Washington, D.C., U.S. Department of Energy.

DP-831, New Mexico Environment Department Discharge Plan.

EPA, 1983. Interim Guidelines and Specifications for Preparing Quality Assurance Project Plans. QAMS-005/80. Washington, D.C., U.S. Environmental Protection Agency.

EPA, 1994. Contract Laboratory Program Volatile Organics Analysis of Ambient Air in Canisters. Washington, D.C., U.S. Environmental Protection Agency.

EPA, 1999. TO-14A, Determination of Volatile Organic Compounds (VOCs) in Ambient Air Using Specially Prepared Canisters with Subsequent Analysis By Gas Chromatography. Compendium of Methods for the Determination of Toxic Organic Compounds in Ambient Air, Research Triangle Park, North Carolina, Quality Assurance Division, Environmental Monitoring Systems Laboratory, U.S. Environmental Protection Agency.

EPA, 2000. Meteorological Monitoring Guidance for Regulatory Modeling Applications. EPA-454/R-99-005, Washington, D.C., U.S. Environmental Protection Agency. 


\section{Waste Isolation Pilot Plant Environmental Monitoring Plan \\ DOE/WIPP 99-2194, Rev. 2}

Mercer, J. W., 1983. Geohydrology of the Proposed Waste Isolation Pilot Plant Site, Los Medanos Area, Southeastern New Mexico. U.S. Geological Survey, Water-Resources Investigations Report 83-4016.

NMED, 1999. Hazardous Waste Facility Permit, \#NM4890139088-TSDF.

OMB, 1975. Reporting Requirements in Connection with the Prevention, Control, and Abatement of Environmental Pollution at Existing Federal Facilities, OMB Circular A-106.

Powers, D. W., S. J. Lambert, S. E. Shaffer, L. R. Hill, W. D. Weart (editors), 1978. Geological Characterization Report, Waste Isolation Pilot Plant (WIPP) Site, Southeastern New Mexico, Sandia National Laboratories Report SAND 78-1596, Vols. 1 and 2. Albuquerque, New Mexico, Sandia National Laboratories.

Public Law 102-579, 106 Stat. 4777. Waste Isolation Pilot Plant Land Withdrawal Act. October 1992, as amended October 1996 by Public Law 104-201.

WTS. WP 02-1, WIPP, Groundwater Monitoring Program Plan. Carlsbad, New Mexico, Washington TRU Solutions LLC.

WTS. WP 02-EM.01, WIPP Meteorological Quality Assurance Plan. Carlsbad, New Mexico, Washington TRU Solutions LLC.

WTS. WP 02-EM1001, Sewage Lagoon Sampling. Carlsbad, New Mexico, Washington TRU Solutions, LLC.

WTS. WP 02-EM1005, Groundwater Serial Sample Analysis. Carlsbad, New Mexico, Washington TRU Solutions LLC.

WTS. WP 02-EM1006, Final Sample and Serial Sample Collection. Carlsbad, New Mexico, Washington TRU Solutions, LLC.

WTS. WP 02-EM1011, Biotic Sampling. Carlsbad, New Mexico, Washington TRU Solutions LLC.

WTS. WP 02-EM1012, Airborne Particulate Sampling. Carlsbad, New Mexico, Washington TRU Solutions LLC.

WTS. WP 02-EM1014, Groundwater Level Measurement. Carlsbad, New Mexico, Washington TRU Solutions LLC.

WTS. WP 02-EM1017, Surface Water and Sediment Sampling for Radiological Analysis. Carlsbad, New Mexico, Washington TRU Solutions LLC.

WTS. WP 02-EM1019, Vegetation Sampling. Carlsbad, New Mexico, Washington TRU Solutions LLC. 
WTS. WP 12-RL.01, Radiochemistry Quality Assurance Plan. Carlsbad, New Mexico, Washington TRU Solutions LLC.

WTS. WP 13-1, Washington TRU Solutions LLC Quality Assurance Program Description. Carlsbad, New Mexico, Washington TRU Solutions LLC.

WTS. WP 15-PR, WIPP Records Management Program. Carlsbad, New Mexico, Washington TRU Solutions LLC. 